\title{
Pyrene-Decoration of a Chromium(0) Tris(diisocyanide) Enhances Excited State Delocalization: A Strategy to Improve the Photoluminescence of $3 d^{6}$ Metal Complexes
}

\author{
Christina Wegeberg, Daniel Häussinger, and Oliver S. Wenger* \\ Cite This: J. Am. Chem. Soc. 2021, 143, 15800-15811 \\ Read Online
}

\begin{abstract}
There is a long-standing interest in iron(II) complexes that emit from metal-to-ligand charge transfer (MLCT) excited states, analogous to ruthenium(II) polypyridines. The $3 \mathrm{~d}^{6}$ electrons of iron(II) are exposed to a relatively weak ligand field, rendering nonradiative relaxation of MLCT states via metal-centered excited states undesirably efficient. For isoelectronic chromium(0), chelating diisocyanide ligands recently provided access to very weak MLCT emission in solution at room temperature. Here, we present a concept that boosts the luminescence quantum yield of a chromium(0) isocyanide complex by nearly 2 orders of magnitude, accompanied by a significant increase of the MLCT lifetime. Pyrene units in the diisocyanide ligand backbone lead to an enlarged $\pi$-conjugation

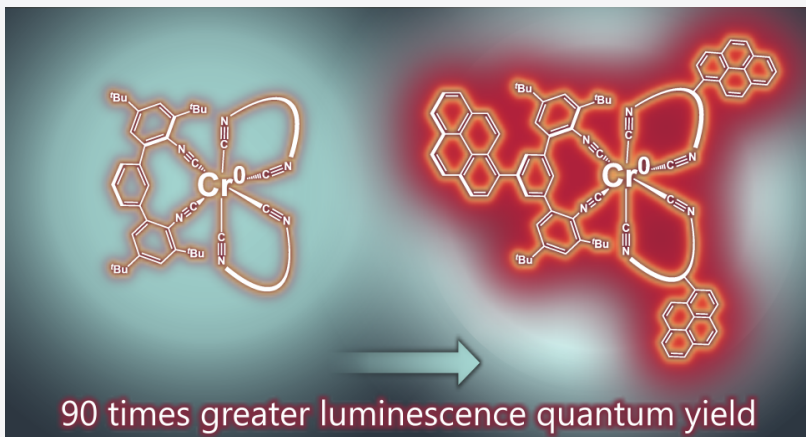
system and to a strongly delocalized MLCT state, from which nonradiative relaxation is less dominant despite a sizable redshift of the emission. While the pyrene moiety is electronically coupled to the core of the chromium $(0)$ complex in the excited state, UV-vis absorption and 2D NMR spectroscopy show that this is not the case in the ground state. Luminescence lifetimes and quantum yields for our pyrenyl-decorated chromium(0) complex exhibit an unusual bell-shaped dependence on solvent polarity, indicative of two counteracting effects governing the MLCT deactivation. These two effects are identified as predominant deactivation either through an energetically nearby lying metal-centered state in the most apolar solvents, or alternatively via direct nonradiative relaxation to the ground state following the energy gap law in more polar solvents. This is the first example of a $3 \mathrm{~d}^{6}$ MLCT emitter to benefit from an increased $\pi$-conjugation network.
\end{abstract}

\section{INTRODUCTION}

The use of earth-abundant elements such as iron, ${ }^{1-9}$ copper, ${ }^{10-15}$ nickel $^{16-21}$ and chromium ${ }^{22-28}$ within the field of photophysics and -chemistry has become an increasingly attractive target over the past decade, ${ }^{29-37}$ and while the goal of inventing cheaper and more sustainable technologies is obvious, ${ }^{38}$ the recent use of first-row transition metals also provides fundamental new challenges and photophysical insights. ${ }^{39} \mathrm{~A}$ widespread approach to obtaining long-lived emissive excited states is to use precious transition metals with the $4 \mathrm{~d}^{6}$ or $5 \mathrm{~d}^{6}$ valence electron configurations such as ruthenium(II), iridium(III), or osmium(II), combined with polypyridine ligands possessing low-energy (unoccupied) $\pi^{*}$ orbitals, for example, $2,2^{\prime}$-bipyridine (bpy). ${ }^{40}$ This arrangement provides access to luminescent metal-to-ligand charge transfer (MLCT) states, where the highest occupied molecular orbital (HOMO) is metal-centered (MC), and the lowest unoccupied molecular orbital (LUMO) is ligand-based. A complicating matter of applying the same strategy to $3 \mathrm{~d}^{6}$ transition metals is, however, the much weaker ligand field splitting experienced by first-row transition metals compared to second- and third-row congeners. ${ }^{39}$ As a consequence, fast nonradiative deactivation of MLCT states through MC excited states becomes important for many first-row transition metal complexes, hereby leading to nonemissive compounds. A textbook example of the struggle with weaker ligand field splitting is that the ${ }^{3} \mathrm{MLCT}$ lifetime of $\left[\mathrm{Ru}(\mathrm{bpy})_{3}\right]^{2+}$ in solution at room temperature is on the order of $500 \mathrm{~ns},{ }^{41}$ whereas for $\left[\mathrm{Fe}(\mathrm{bpy})_{3}\right]^{2+}$, it is only ca. $50 \mathrm{fs}$ under comparable conditions. ${ }^{42,43}$ In recent years, this fundamental issue has been addressed by extensive ligand developments, many of which aim to destabilize the MC excited states by using ligands with strong $\sigma$-donor properties (to raise the $\mathrm{e}_{\mathrm{g}}$-orbitals in energy) and/or strong $\pi$-acceptor character (to stabilize the $t_{2 g}$-orbitals). ${ }^{9,30}$ Many of these efforts concentrated on influencing the $\mathrm{MC}$ excited states through ligand design, ${ }^{44}$

Received: July 15, 2021

Published: September 13, 2021 
while others focused on tuning of the MLCT states of $3 \mathrm{~d}^{6}$ complexes. $3,45,46$

Extending the $\pi$-conjugation of the acceptor ligand to obtain more strongly delocalized MLCT excited states is a wellestablished strategy to improve the photophysical properties of ruthenium(II) and osmium(II) diimine complexes. ${ }^{47-55}$ Delocalization of the MLCT-excited electron over a greater $\pi$-conjugated ligand framework can help minimize excited-state distortions and changes along important nuclear coordinates $\left(\Delta \mathrm{Q}_{e}\right)$, leading to a smaller overlap between vibrational wave functions of the ground and excited state potential energy surfaces. As a consequence, nonradiative decay rates decrease, and excited-state lifetimes are elongated. Until now, this strategy has however not been applicable to $3 \mathrm{~d}^{6}$ MLCT emitters.

One approach to extend the $\pi$-conjugation of a ligand framework is to attach additional aromatic groups, such as, for example, pyrenyl. When those additional groups are electronically decoupled from the rest of the metal complex, there can be mutually independent MLCT and ligand-centered (LC) excited states, with the latter localized on the tethered organic group. ${ }^{56-60}$ Reversible energy transfer between a ${ }^{3} \mathrm{MLCT}$ and a ${ }^{3} \mathrm{LC}$ state can take place as long as the two states are nearly isoenergetic, and this is often the case for ruthenium(II)pyrene systems. ${ }^{56,60-69}$ Since deactivation from the ${ }^{3} \mathrm{LC}$ state is inherently slow, this (dark) state can serve as an energy reservoir feeding the emissive ${ }^{3} \mathrm{MLCT}$ state over time, thereby extending the lifetime of the ${ }^{3}$ MLCT state considerably. This triplet reservoir effect has primarily been explored for ruthenium(II) compounds, ${ }^{70-74}$ but there are also examples of osmium(II), ${ }^{74-77}$ iridium(III), ${ }^{78-80}$ platinum(II), ${ }^{81-84}$ and rhenium(I) complexes. ${ }^{85}$

More recently, there have been several attempts to increase the ${ }^{3}$ MLCT lifetime of iron(II) complexes by taking advantage of the delocalization effect (through increased $\pi$-conjugation of the ligand framework $)^{5,6,86}$ or the triplet reservoir effect. ${ }^{87}$ However, the ${ }^{3}$ MLCT states of iron(II) complexes known so far are nonluminescent, and consequently, it was interesting to focus instead on isoelectronic chromium(0), for which we have recently reported an isocyanide complex that emits very weakly from a ${ }^{3}$ MLCT state. ${ }^{88}$ Following early studies of group 6 metal complexes with isocyanide ligands ${ }^{89,90}$ and recent reports of luminescent $\mathrm{W}^{0}$ complexes with monodentate isocyanides, $^{91-93}$ our group discovered that chelating diisocyanide ligands facilitate access to molybdenum $(0)$ complexes with brightly emissive ${ }^{3}$ MLCT excited states. ${ }^{94-96}$ However, the chromium $(0)$ complex $\left[\mathrm{Cr}\left(\mathrm{L}^{\mathrm{H}}\right)_{3}\right]$ (Scheme 1) exhibited only extremely weak ${ }^{3} \mathrm{MLCT}$ luminescence with a quantum yield of ca. $10^{-5}$ in tetrahydrofuran (THF) at room temperature. ${ }^{88}$ The energy of the emissive ${ }^{3} \mathrm{MLCT}$ state of $\left[\mathrm{Cr}\left(\mathrm{L}^{\mathrm{H}}\right)_{3}\right]$ was previously estimated to $2.05 \mathrm{eV}$, close to the triplet energy of pyrene $(2.10 \mathrm{eV}) .^{97}$ In an attempt to increase the luminescence quantum yield and the ${ }^{3} \mathrm{MLCT}$ lifetime of chromium $(0)$ isocyanide complexes and to explore the effects of an extended $\pi$-system at the ligand periphery of an emissive $3 \mathrm{~d}^{6}$ complex, we attached a pyrene unit on the backbone of the diisocyanide ligand, affording the complex $\left[\mathrm{Cr}\left(\mathrm{L}^{\mathrm{pyr}}\right)_{3}\right]$ (Scheme 1). The pyrene moiety could potentially work as either a triplet reservoir for the luminescent ${ }^{3} \mathrm{MLCT}$ state of $\left[\mathrm{Cr}\left(\mathrm{L}^{\mathrm{pyr}}\right)_{3}\right]$, or the extension of the $\pi$-system on the ligand could lead to a more delocalized ${ }^{3} \mathrm{MLCT}$ state for $\left[\mathrm{Cr}\left(\mathrm{L}^{\mathrm{pyr}}\right)_{3}\right]$ than for $\left[\mathrm{Cr}\left(\mathrm{L}^{\mathrm{H}}\right)_{3}\right]$. The outcome is expected to depend on the strength of the electronic coupling between the diisocyanide
Scheme 1. Molecular Structures of the $\left[\mathrm{Cr}\left(\mathrm{L}^{\mathrm{H}}\right)_{3}\right]$ Complex Investigated Previously, ${ }^{88}$ and the $\left[\mathrm{Cr}\left(\mathrm{L}^{\mathrm{pyr}}\right)_{3}\right]$ Compound Investigated in This Work

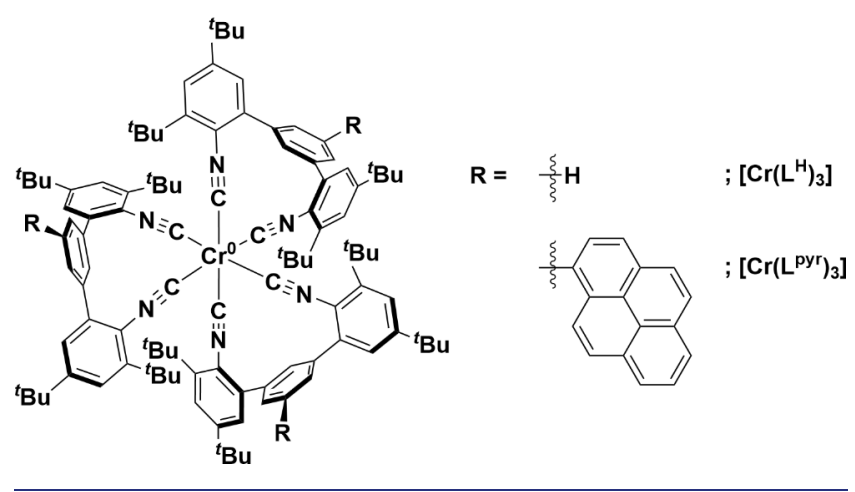

framework and the pyrene in the excited state, but either one of the two above-mentioned effects (i.e., either the triplet reservoir effect or the delocalization effect) should potentially enhance the photophysical and photochemical properties of $\left[\mathrm{Cr}\left(\mathrm{L}^{\mathrm{pyr}}\right)_{3}\right]$ compared to $\left[\mathrm{Cr}\left(\mathrm{L}^{\mathrm{H}}\right)_{3}\right]$. Our study demonstrates that this is indeed the case and that the delocalization effect plays a dominant role for $\left[\mathrm{Cr}\left(\mathrm{L}^{\mathrm{pyr}}\right)_{3}\right]$. Furthermore, our work provides new insight into the competition between different nonradiative MLCT excited-state deactivation pathways, which play a crucial role in photoactive complexes of first-row transition metals.

\section{RESULTS AND DISCUSSION}

Synthesis and Ground State Characterization of $\left[\mathrm{Cr}\left(\mathrm{L}^{\mathrm{pyr}}\right)_{3}\right]$. The ligand $\mathrm{L}^{\mathrm{pyr}}$ was synthesized in a total of nine steps (Scheme 2) using the commercially available 3,5dibromoanisole and 3,5-di(tert-butyl)bromobenzene as starting materials. In the first steps, 3,5-dibromoanisole was converted to the diboronic ester $\mathbf{1}$, and nitration of 3,5-di(tertbutyl)bromobenzene yielded 2 , hereby enabling a subsequent Suzuki-Miyaura coupling of $\mathbf{1}$ and $\mathbf{2}$. The methoxybenzene unit of the coupling product 3 was first converted to the phenolic product 4 and subsequently to the aryl triflate 5 . After reduction of the two nitro groups to the dianiline 6, formylation with $\mathrm{HCOOH}$ gave the diformamide 7 . In a Suzuki-Miyaura coupling with commercial pyrene-1-boronic acid, a pyrene moiety was incorporated in the ligand backbone of 8, and finally, dehydration with $\mathrm{POCl}_{3}$ afforded the diisocyanide ligand $\mathrm{L}^{\mathrm{pyr}}$. The homoleptic chromium(0) complex of $\mathrm{L}^{\mathrm{pyr}}$ was prepared using a synthetic strategy similar to that used for $\left[\mathrm{Cr}\left(\mathrm{L}^{\mathrm{H}}\right)_{3}\right]$, 8 where $\left[\mathrm{Cr}(\mathrm{THF})_{3} \mathrm{Cl}_{3}\right]$ was prepared from $\mathrm{CrCl}_{3}$, and subsequently reacted with $\mathrm{L}^{\text {pyr }}$ over $\mathrm{Na} / \mathrm{Hg}$ in dry THF at room temperature to form the deep red $\left[\mathrm{Cr}\left(\mathrm{L}^{\mathrm{pyr}}\right)_{3}\right]$ complex. The crude was purified by precipitation from $n$-hexane at $-34{ }^{\circ} \mathrm{C}$ to afford $\left[\mathrm{Cr}\left(\mathrm{L}^{\mathrm{pyr}}\right)_{3}\right]$ in $22 \%$ yield. Synthetic procedures and product characterization can be found in the Supporting Information.

The $\mathrm{C} \equiv \mathrm{N}$ stretching vibration in the solid-state IR spectrum of $\mathrm{L}^{\mathrm{pyr}}$ is located at $2112 \mathrm{~cm}^{-1}$ (Figure S11), and upon coordination to $\mathrm{Cr}^{0}$ in $\left[\mathrm{Cr}\left(\mathrm{L}^{\mathrm{pyr}}\right)_{3}\right]$ it shifts to $1950 \mathrm{~cm}^{-1}$. This is a manifestation of $\pi$-backbonding from the zerovalent metal center to the $\pi^{*}$ antibonding orbital of the isocyanide moiety, ${ }^{99-101}$ and similar $\mathrm{C} \equiv \mathrm{N}$ stretch frequencies have been reported for $\mathrm{L}^{\mathrm{H}}$ and $\left[\mathrm{Cr}\left(\mathrm{L}^{\mathrm{H}}\right)_{3}\right]$, respectively. ${ }^{88}$ Upon complexation of $\mathrm{L}^{\mathrm{pyr}}$ to chromium $(0)$, a strong absorbance appears in 
Scheme 2. Synthesis of the Chelating Diisocyanide Ligand $\mathrm{L}^{\text {pyra }}$

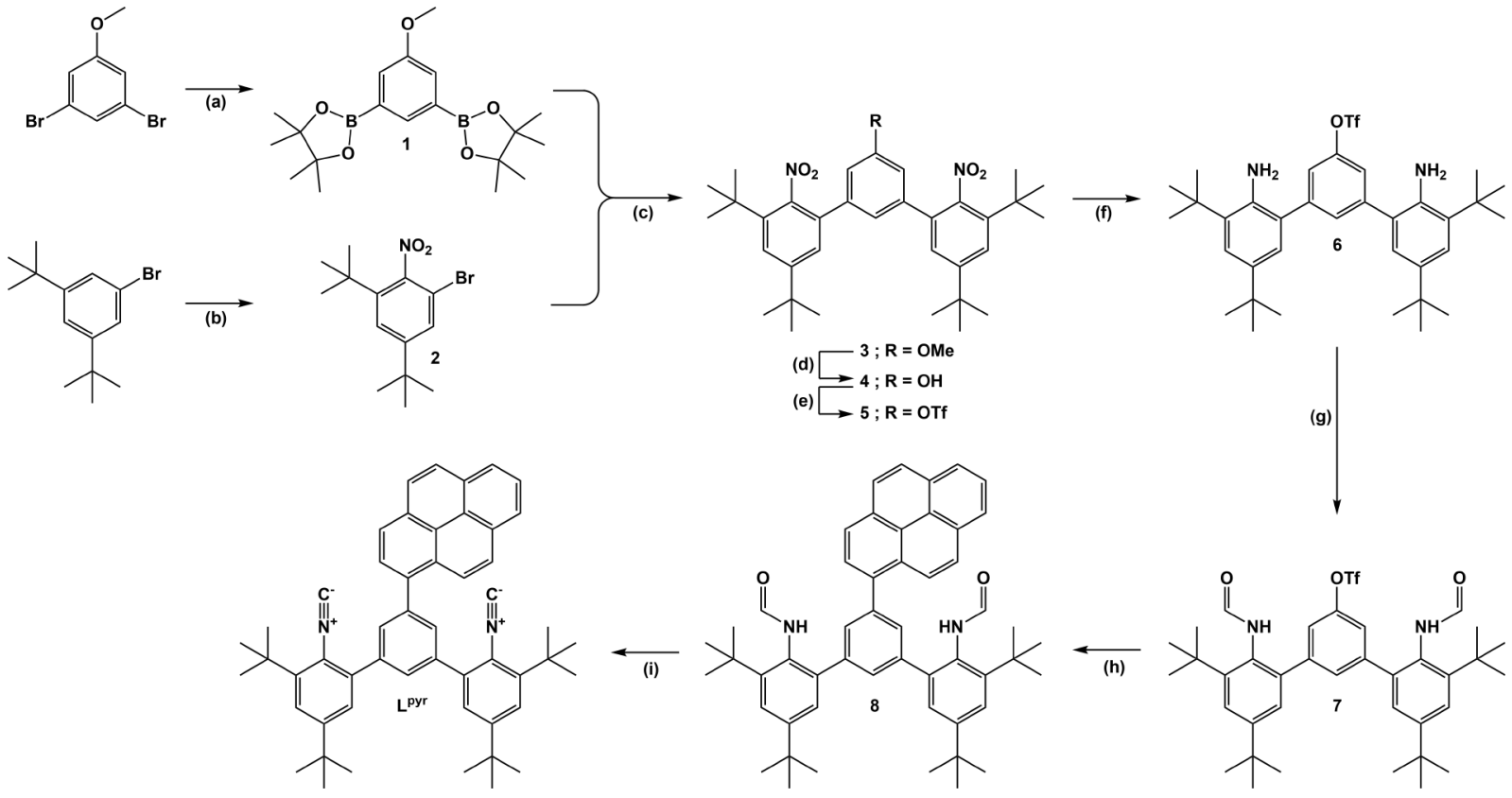

a (a) bis(pinacolato)diboron, [ $\left.\mathrm{PdCl}_{2}\left(\mathrm{PPh}_{3}\right)_{2}\right]$, KOAc, iso-propanol, reflux; (b) $\mathrm{CH}_{3} \mathrm{COOH}, \mathrm{H}_{2} \mathrm{SO}_{4}$, fuming $\mathrm{HNO}_{3}, 80{ }^{\circ} \mathrm{C}$; (c) [PdCl $\left.2(\mathrm{dppf})\right]$, $\mathrm{K}_{2} \mathrm{CO}_{3}$, 1,4-dioxane/ $\mathrm{H}_{2} \mathrm{O}$ 2:1, reflux; (d) $\mathrm{BBr}_{3}, \mathrm{CH}_{2} \mathrm{Cl}_{2}$, rt; (e) (TfO) ${ }_{2} \mathrm{O}$, pyridine, rt; (f) $\mathrm{Zn}, \mathrm{CH}_{3} \mathrm{COOH} / \mathrm{EtOH} \mathrm{1:2,} \mathrm{rt;} \mathrm{(g)} \mathrm{HCOOH,} \mathrm{acetic}$ anhydride, $100{ }^{\circ} \mathrm{C}(\mathrm{h})\left[\mathrm{Pd}\left(\mathrm{PPh}_{3}\right)_{4}\right], \mathrm{K}_{2} \mathrm{CO}_{3}, 1$,4-dioxane $/ \mathrm{H}_{2} \mathrm{O} 4: 1$, reflux; (i) $\mathrm{POCl}_{3}, \mathrm{NH}(i \text {-propyl })_{2}, \mathrm{CH}_{2} \mathrm{Cl}_{2}$, rt. The yield was $20 \%$ over eight steps with respect to 3,5 -dibromoanisole.

the IR spectrum at $590 \mathrm{~cm}^{-1}$, and this band is attributable to the $\mathrm{Cr}-\mathrm{C}$ stretching vibration.

NMR analysis of a solution of the free $L^{\text {pyr }}$ ligand in $\mathrm{C}_{6} \mathrm{D}_{6}$ yielded the complete assignment of all proton and carbon spins including the isocyanide carbon atom at $175.6 \mathrm{ppm}$ (Figure S1 and S2). A pulsed field gradient spin echo experiment furthermore revealed a translational diffusion coefficient of $\mathrm{D}$ $=4.92 \times 10^{-10} \mathrm{~m}^{2} / \mathrm{s}$ in $\mathrm{C}_{6} \mathrm{D}_{6}$ at $298 \mathrm{~K}$ (Figure S9). As expected, the spectra evidenced an effective 2-fold symmetry for the ligand, and the NOE pattern indicates free rotation of the three benzene rings of the $m$-terphenyl with respect to each other as well as unhindered rotation of the pyrene moiety. An entirely different picture is, however, observed upon coordination of $\mathrm{L}^{\mathrm{pyr}}$ to the $\mathrm{Cr}^{0}$ center: The isocyanide carbon shifts by more than $20 \mathrm{ppm}$ downfield to several broad and weak signals around $197.3 \mathrm{ppm}$ (Figure S13) and the translational diffusion coefficient decreases to $3.37 \times 10^{-10} \mathrm{~m}^{2} / \mathrm{s}$ (Figure $\mathrm{S} 14$ ) as a consequence of the larger hydrodynamic radius of $\left[\mathrm{Cr}\left(\mathrm{L}^{\mathrm{pyr}}\right)_{3}\right]$ relative to $L^{\text {pyr }}$. Assuming perfectly spherical molecules and ideal validness of the Stokes-Einstein equation, ${ }^{102}$ an increase of the molecular weight by a factor of 3.1 is obtained, which is in excellent agreement with the theoretical factor of 3.074 derived from the net formula. In addition, the symmetry of the ligand signals is no longer observed for $\left[\mathrm{Cr}\left(\mathrm{L}^{\mathrm{pyr}}\right)_{3}\right]$ and broad, featureless resonances are instead obtained at room temperature, clearly suggesting dynamic processes on the ms time scale (Figure S12). We, therefore, performed variable temperature NMR experiments between 230 and $338 \mathrm{~K}$ in toluene- $\mathrm{D}_{8}$ (Figures S15-S16). The series of complex spectra can be summarized as follows: at high temperature, a fast exchange regime is observed with an effectively $D_{3}$ symmetry of $\left[\mathrm{Cr}\left(\mathrm{L}^{\mathrm{pyr}}\right)_{3}\right]$, where the three ligands around the $\mathrm{Cr}^{0}$ center are effectively magnetically equivalent. Around $280 \mathrm{~K}$, the three $\mathrm{L}^{\text {pyr }}$ ligands of $\left[\mathrm{Cr}\left(\mathrm{L}^{\mathrm{pyr}}\right)_{3}\right]$ are no longer symmetry equivalent, and three individual and relatively sharp sets of exchanging resonances with equal intensity are clearly observed for the pyrene moiety as well as for the para-located proton of the central ring $\left(\mathrm{H}_{\mathrm{A}}\right.$, see insert in Figure 1) at very low field (9.40, 9.30, and $8.94 \mathrm{ppm})$. This strongly indicates a conformation of $\left[\mathrm{Cr}\left(\mathrm{L}^{\mathrm{pyr}}\right)_{3}\right]$ with $\mathrm{C}_{1}$ symmetry and an activation barrier of $65 \mathrm{~kJ} / \mathrm{mol}$ for the interconversion of the three ligands. Upon further cooling, the $\mathrm{H}_{\mathrm{A}}$ resonances broaden again and split at $230 \mathrm{~K}$ into at least one additional

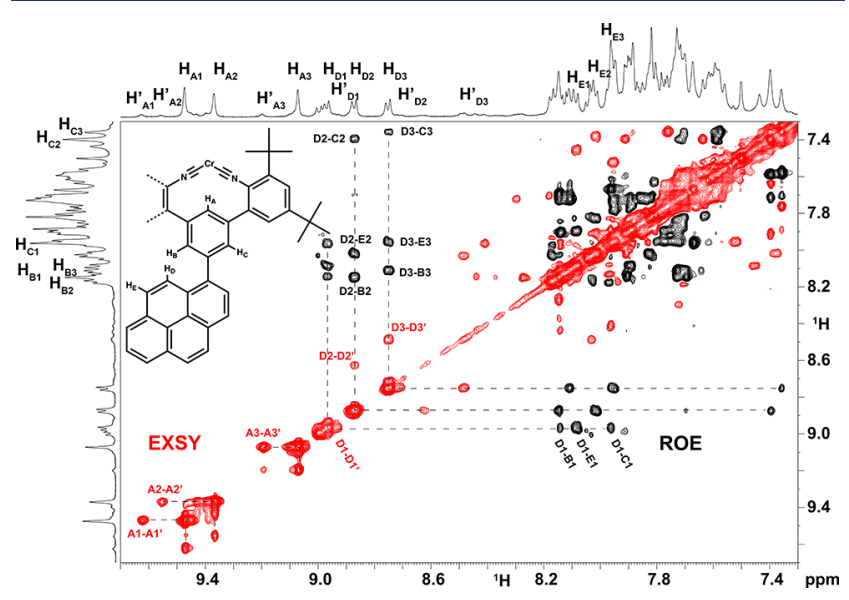

Figure 1. Section of the ROESY spectrum of $\left[\mathrm{Cr}\left(\mathrm{L}^{\mathrm{pyr}}\right)_{3}\right]$ in toluene$\mathrm{D}_{8}(600 \mathrm{MHz}, 230 \mathrm{~K})$. ROE and EXSY peaks are seen in black and red, respectively, and are partially assigned. Inset: Chemical representation of $\left[\mathrm{Cr}\left(\mathrm{L}^{\mathrm{pyr}}\right)_{3}\right]$ with specification of protons $\mathrm{H}_{\mathrm{A}}$ to $\mathrm{H}_{\mathrm{E}}$. At $230 \mathrm{~K}$ two distinct $\mathrm{C}_{1}-$ symmetric conformers of $\left[\mathrm{Cr}\left(\mathrm{L}^{\mathrm{pyr}}\right)_{3}\right]$ exist on the time scale of the ROESY experiment, and the individual protons associated with each conformer are marked with and without an apostrophe, respectively. 
set of resonances $\left(\mathrm{H}_{\mathrm{A} 1}\right.$ to $\mathrm{H}_{\mathrm{A} 3}$ ), and exchange peaks (EXSY) are observed in the ROESY spectrum at $230 \mathrm{~K}$ (Figure 1), suggesting that two conformers of $\left[\mathrm{Cr}\left(\mathrm{L}^{\mathrm{pyr}}\right)_{3}\right]$ interconvert on the ROESY time scale, this with a significantly lower activation barrier of $51 \mathrm{~kJ} / \mathrm{mol}$.

Similar to the situation at $280 \mathrm{~K}$, the overall $\mathrm{Cr}^{0}$ complex shows no symmetry elements at $230 \mathrm{~K}$ whatsoever, and a strong distortion of the ideal octahedral symmetry must prevail. This observation in solution is consistent with the previously reported $\mathrm{C}_{1}$ symmetry found in the crystal structure of $\left[\mathrm{Cr}\left(\mathrm{L}^{\mathrm{H}}\right)_{3}\right] .{ }^{88}$ While a complete assignment of all 102 aromatic carbons in the NMR spectrum of $\left[\mathrm{Cr}\left(\mathrm{L}^{\mathrm{pyr}}\right)_{3}\right]$ was not feasible due to massive overlap even in the $2 \mathrm{D}$ spectra, it was possible to unambiguously assign the crucial protons $\mathrm{H}_{\mathrm{A}}$ to $\mathrm{H}_{\mathrm{E}}$ in all three different ligand environments (Figures 1 and S15), and a careful analysis of the ROE pattern between $\mathrm{H}_{\mathrm{D}}$ and $\mathrm{H}_{\mathrm{B}}$ / $\mathrm{H}_{\mathrm{C}}$ clearly indicates that the pyrene rings no longer rotate freely, nor are they trapped in an orthogonal orientation relative to the central benzene ring, as the corresponding $\mathrm{ROE}$ intensities (e.g., D3-B3 vs D3-C3) are clearly of different magnitude. It can consequently be assumed that either a static or a dynamic tilted orientation brings, e.g., $\mathrm{H}_{\mathrm{D} 3}$ in closer vicinity to $\mathrm{H}_{\mathrm{B} 3}$ compared to $\mathrm{H}_{\mathrm{C} 3}$.

Analogously to the aromatic protons, the methyl resonances of the ortho tert-butyl groups also show one signal at $338 \mathrm{~K}$ and split up to six resonances for a $\mathrm{C}_{1}$-symmetric complex below $280 \mathrm{~K}$ and finally experience further splitting at $230 \mathrm{~K}$ (Figure S16) to at least two interconverting conformers as indicated by EXSY correlation peaks. Virtually identical behavior was obtained for the para tert-butyl protons. The observed line width of ca. $10 \mathrm{~Hz}$ for the ortho tert-butyl groups at $230 \mathrm{~K}$ is almost twice as large as the line width found for the para tertbutyl (ca. $6 \mathrm{~Hz}$ ) or the aromatic protons of the central ring or the pyrene moieties (ca. $4 \mathrm{~Hz}$ ) and is, therefore, evidence for a lower coalescence temperature for the ortho tert-butyl protons compared to the other protons. This strongly suggests that the underlying dynamic process is centered on these ortho tertbutyl groups-a hypothesis that is corroborated by the low activation barrier as discussed above and seems plausible considering the steric clashes of these tert-butyl substituents ${ }^{95}$ in $\left[\mathrm{Cr}\left(\mathrm{L}^{\mathrm{pyr}}\right)_{3}\right]$.

Dilute solutions of $\left[\mathrm{Cr}\left(\mathrm{L}^{\mathrm{pyr}}\right)_{3}\right]$ exhibit a deep red color, and the UV-vis spectrum shows a broad MLCT absorption band between 400 and $600 \mathrm{~nm}\left(\varepsilon_{473 \mathrm{~nm}} \approx 32000 \mathrm{M}^{-1} \mathrm{~cm}^{-1}\right)$, which is also present in the spectrum of the $\left[\mathrm{Cr}\left(\mathrm{L}^{\mathrm{H}}\right)_{3}\right]$ parent complex (solid blue and gray traces in Figures 2a, and Figure S18). Ligand-centered $\pi-\pi^{*}$ transitions originating from the pyrene moiety appear at 280 and $345 \mathrm{~nm}$ both in the UV-vis spectra of $\mathrm{L}^{\mathrm{pyr}}$ and $\left[\mathrm{Cr}\left(\mathrm{L}^{\mathrm{pyr}}\right)_{3}\right]$ (solid black and blue traces in Figure $2 \mathrm{a}$, respectively), and at shorter wavelengths, ligandcentered $\pi-\pi^{*}$ transitions from the isocyanide ligand framework appear. The UV-vis absorption spectrum of $\left[\mathrm{Cr}\left(\mathrm{L}^{\mathrm{pyr}}\right)_{3}\right]$ is largely solvent invariant (Figure S19), and there is no indication for significant electronic coupling between the pyrene unit and the core part of the $\left[\mathrm{Cr}\left(\mathrm{L}^{\mathrm{pyr}}\right)_{3}\right]$ complex in the ground state, as the overall absorption spectrum basically is a linear combination of the absorption spectra of its individual components. This observation is in agreement with our NMR analysis, as the 2D NMR experiments exclude a coplanar arrangement of the pyrene unit relative to the central ring of the $m$-terphenyl backbone in the electronic ground state.

Luminescence Properties and Excited State Dynamics. Upon excitation into the MLCT absorption band of

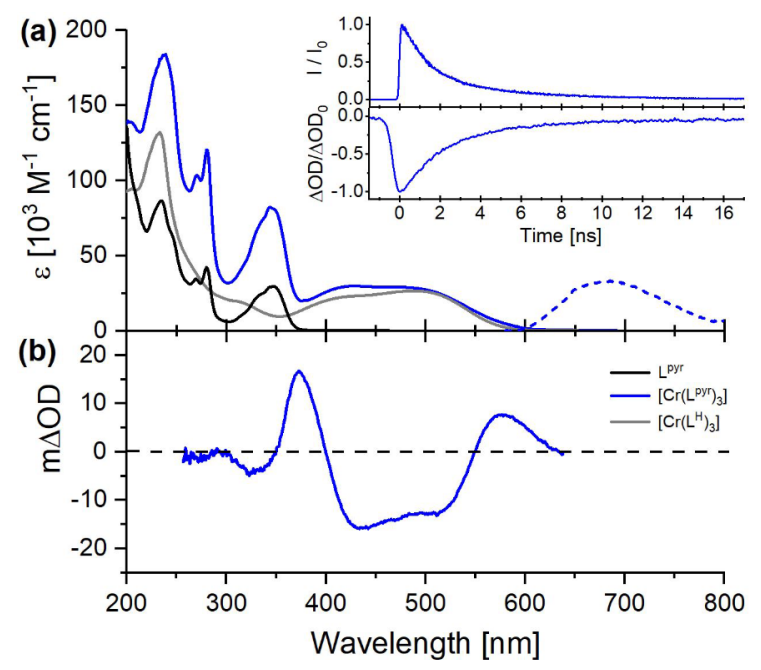

Figure 2. (a) UV-vis absorption spectra of $\left[\mathrm{Cr}\left(\mathrm{L}^{\text {pyr }}\right)_{3}\right]$ (solid blue), free $\mathrm{L}^{\mathrm{pyr}}$ ligand (black) and $\left[\mathrm{Cr}\left(\mathrm{L}^{\mathrm{H}}\right)_{3}\right]$ parent complex (gray), as well as the normalized luminescence spectrum of $\left[\mathrm{Cr}\left(\mathrm{L}^{\mathrm{pyr}}\right)_{3}\right]$ (dashed blue). Inset: Luminescence decay at $675 \mathrm{~nm}$ and the recovery of the ground state MLCT bleach at $430 \mathrm{~nm}$ after pulsed excitation of $\left[\mathrm{Cr}\left(\mathrm{L}^{\mathrm{pyr}}\right)_{3}\right]$ at $473 \mathrm{~nm}$. (b) Transient absorption spectrum of $\left[\mathrm{Cr}\left(\mathrm{L}^{\mathrm{pyr}}\right)_{3}\right](20 \mu \mathrm{M})$. The signal was time-integrated for $3 \mathrm{~ns}$ immediately after excitation with pulses of ca. $30 \mathrm{ps}$ duration. All data sets were recorded in deaerated $n$-hexane at $20{ }^{\circ} \mathrm{C}$, and excitation occurred at $473 \mathrm{~nm}$ in all cases. See Supporting Information for analogous data recorded in other solvents.

$\left[\mathrm{Cr}\left(\mathrm{L}^{\mathrm{pyr}}\right)_{3}\right]$ at $473 \mathrm{~nm}$, broad unstructured luminescence is observed in deaerated $n$-hexane at $20{ }^{\circ} \mathrm{C}$ (dashed blue trace in Figure 2a). The emission maxima $\left(\lambda_{\mathrm{em}}\right)$ for $\left[\mathrm{Cr}\left(\mathrm{L}^{\mathrm{pyr}}\right)_{3}\right]$ and $\left[\mathrm{Cr}\left(\mathrm{L}^{\mathrm{H}}\right)_{3}\right]$ in deaerated $n$-hexane are at 675 and $625 \mathrm{~nm}$ (Table 1), ${ }^{88}$ respectively, hence the incorporation of the extended $\pi$-system into the diisocyanide ligand framework causes a substantial redshift. Slightly less apolar solvents than $n$-hexane readily induce a further redshift of the emission for $\left[\mathrm{Cr}\left(\mathrm{L}^{\mathrm{pyr}}\right)_{3}\right]$ (Figure 3a): for example, in $p$-xylene, the emission band maximum is at $724 \mathrm{~nm}$; in di-n-butyl ether, it is at 752 $\mathrm{nm}$, and in 1,4-dioxane, it approaches the limit of the detectable wavelength range of our photomultiplier tube $\left(\lambda_{\mathrm{em}}\right.$ $=774 \mathrm{~nm})$.

In THF and more polar solvents, no emission is observable in the accessible detection window $(<800 \mathrm{~nm})$. The redshift in emission band maxima correlates well with the solvent polarity scale SPP ${ }^{104}$ (Figure S23), whereas other measures such as the refractive index or dielectric constants (including a LippertMataga analysis $)^{105,106}$ give poorer correlations with our emission data (Figures S24-S26). The SPP scale is rather sensitive to changes in nonspecific solvent effects, which seems to be key to the correlation with the data sets of $\left[\mathrm{Cr}\left(\mathrm{L}^{\mathrm{pyr}}\right)\right]_{3}$, as these are obtained in a relatively apolar solvent range. Concentration-dependent UV-vis absorption and emission studies provided no evidence for excimer formation (Figure S21), suggesting that intermolecular aggregation effects play a negligible role despite the presence of three peripheral pyrene units per complex that could potentially undergo $\pi$-stacking interactions. Furthermore, as similar luminescence spectra are obtained for toluene and di- $n$-butyl ether, the aromaticity of the solvent does not appear to be a key determinant for the emission behavior (Figure 3, orange and red traces).

The photoluminescence of $\left[\mathrm{Cr}\left(\mathrm{L}^{\mathrm{pyr}}\right)_{3}\right]$ is considerably more solvatochromic than that of the previously investigated 
Table 1. Emission Band Maxima $\left(\lambda_{\mathrm{em}}\right),{ }^{3}$ MLCT Excited-State Lifetimes $(\tau)$ and Luminescence Quantum Yields $(\varphi)$ for $\left[\mathrm{Cr}\left(\mathrm{L}^{\mathrm{pyr}}\right)_{3}\right]\left(\lambda_{\text {exc }}\right.$ at $\left.473 \mathrm{~nm}\right)$ and $\left[\mathrm{Cr}\left(\mathrm{L}^{\mathrm{H}}\right)_{3}\right]\left(\lambda_{\text {exc }}\right.$ at $\left.532 \mathrm{~nm}\right)$ in Deaerated Solutions at $20{ }^{\circ} \mathrm{C}^{b}$

\begin{tabular}{clcccc} 
Complex & \multicolumn{1}{c}{ Solvent } & $\lambda_{\text {em },}[\mathrm{nm}]$ & $\tau_{1} \tau_{2}[\mathrm{~ns}]$ & $\tau_{\text {avg }}[\mathrm{ns}]$ & $\varphi^{b}$ \\
{$\left[\mathrm{Cr}\left(\mathrm{L}^{\mathrm{pyr}}\right)_{3}\right]$} & $n$-hexane & 675 & $1.57(69 \%), 5.61(31 \%)$ & 2.82 & $3 \times 10^{-4}$ \\
& Cyclooctane & 682 & $4.05(48 \%), 8.00(52 \%)$ & 6.10 & $9 \times 10^{-4}$ \\
{$\left[\mathrm{Cr}\left(\mathrm{L}^{\mathrm{H}}\right)_{3}\right]^{88}$} & $n$-hexane & 625 & $0.32(80 \%), 3.73(20 \%)$ & 1.00 & $\mathrm{~N} / \mathrm{A}$ \\
& THF & 635 & $2.20(100 \%)$ & 2.20 & $1 \times 10^{-5}$
\end{tabular}

${ }^{a}$ See Table S1 for a complete list of investigated solvents for $\left[\mathrm{Cr}\left(\mathrm{L}^{\mathrm{pyr}}\right)_{3}\right] .{ }^{{ }^{b}}$ The luminescence quantum yields were determined relative to aerated acetonitrile solutions of $\left[\mathrm{Ru}(\mathrm{bpy})_{3}\right]\left(\mathrm{PF}_{6}\right)_{2}$ at $20{ }^{\circ} \mathrm{C}(\varphi=0.018) .{ }^{103}$
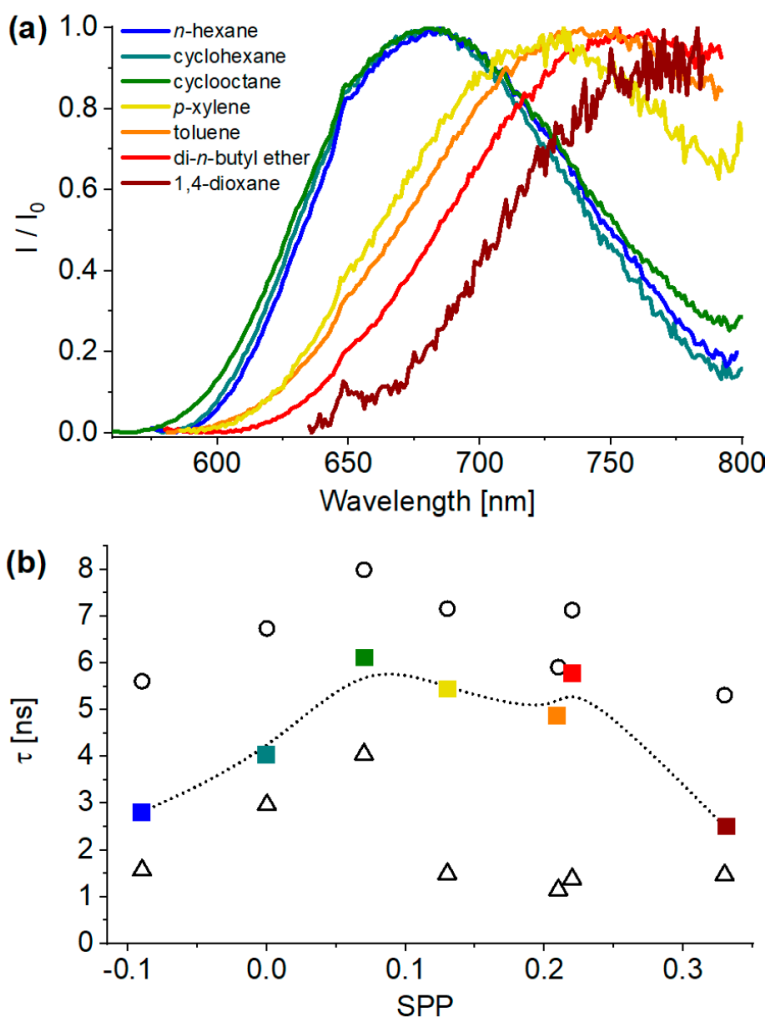

Figure 3. (a) Normalized steady-state emission spectra of $\left[\mathrm{Cr}\left(\mathrm{L}^{\mathrm{pyr}}\right)_{3}\right]$ in various deaerated solvents at $20^{\circ} \mathrm{C}$ following excitation at $473 \mathrm{~nm}$. (b) Correlation between the SPP scale ${ }^{104}$ and the luminescence lifetimes of $\left[\mathrm{Cr}\left(\mathrm{L}^{\mathrm{pyr}}\right)_{3}\right]$. All luminescence decays were fitted with biexponential functions (see Table S1). The open triangles and open circles represent the shorter $\left(\tau_{1}\right)$ and longer lifetime components $\left(\tau_{2}\right)$, respectively. The colored solid squares represent the weighted average lifetimes $\left(\tau_{\text {avg }}\right)$, and the dotted trace is a guide to aid the eye connecting the squares. There is no physical model supporting the dotted line.

$\left[\mathrm{Cr}\left(\mathrm{L}^{\mathrm{H}}\right)_{3}\right]$ complex in which a redshift of only $5 \mathrm{~nm}$ is observed when going from $n$-hexane to toluene, whereas a redshift of $65 \mathrm{~nm}$ is detectable for $\left[\mathrm{Cr}\left(\mathrm{L}^{\mathrm{prr}}\right)_{3}\right]^{\prime}$. Increasing solvent polarity commonly causes a stabilization of MLCT states due to improved stabilization of charges, and the much more strongly pronounced solvatochromic effect observed for $\left[\mathrm{Cr}\left(\mathrm{L}^{\mathrm{pyr}}\right)_{3}\right]$ suggests that the change in dipole moment between the ground state and the emissive ${ }^{3} \mathrm{MLCT}$ state is larger in $\left[\mathrm{Cr}\left(\mathrm{L}^{\mathrm{pyr}}\right)_{3}\right]$ relative to that of $\left[\mathrm{Cr}\left(\mathrm{L}^{\mathrm{H}}\right)_{3}\right]$ and furthermore that the nature of the ${ }^{3} \mathrm{MLCT}$ states differs substantially between the two complexes. Even in frozen matrices at $77 \mathrm{~K}$, the emission of $\left[\mathrm{Cr}\left(\mathrm{L}^{\mathrm{pyr}}\right)_{3}\right]$ exhibits nonnegligible solvent dependence. For instance, in isopentane, the emission band maximum is at $676 \mathrm{~nm}$ while in 2-methyl-THF, it is at $692 \mathrm{~nm}$ (Figure S22).
The luminescence decays of $\left[\mathrm{Cr}\left(\mathrm{L}^{\mathrm{pyr}}\right)_{3}\right]$ in all seven investigated solvents ( $n$-hexane, cyclohexane, cyclooctane, $p$ xylene, toluene, di-n-butyl ether, and 1,4-dioxane) follow biexponential kinetics (Figure S27, Table S1), analogous to what we previously found for $\left[\mathrm{Cr}\left(\mathrm{L}^{\mathrm{H}}\right)_{3}\right]$ and $\left.\left[\mathrm{Mo}\left(\mathrm{L}^{\mathrm{H}}\right)_{3}\right]\right]^{88,107}$ While our NMR analysis of $\left[\mathrm{Cr}\left(\mathrm{L}^{\mathrm{prr}}\right)_{3}\right]$ in principle only is representative for the ground state properties of $\left[\mathrm{Cr}\left(\mathrm{L}^{\mathrm{pyr}}\right)_{3}\right]$, it is reassuring that we indeed see two different conformers on the NMR time scale (ms). The structural origin of this effect very likely lies in the sterically demanding ortho tert-butyl groups (Figure S16), which preclude rapid interconversion of different conformers into one another on the time scale of the time-resolved laser experiments. The two conformers of $\left[\mathrm{Cr}\left(\mathrm{L}^{\mathrm{pyr}}\right)_{3}\right]$ have slightly different luminescence lifetimes (Table S1), and it seems that solvents with an "intermediate" solvent polarity (SPP index of 0.13 to 0.21 ) favor to a larger degree the conformer with a relatively longer luminescence lifetime. In deaerated cyclooctane at $20{ }^{\circ} \mathrm{C}$, the ${ }^{3} \mathrm{MLCT}$ luminescence of $\left[\mathrm{Cr}\left(\mathrm{L}^{\mathrm{pyr}}\right)_{3}\right]$ decays with time constants of $\tau_{1}=$ $4.05 \mathrm{~ns}(48 \%)$ and $\tau_{2}=8.00 \mathrm{~ns}(52 \%)$, resulting in a weighted average lifetime $\left(\tau_{\text {avg }}\right)$ of $6.10 \mathrm{~ns}$. To the best of our knowledge, this is the longest ${ }^{3}$ MLCT lifetime for any $3 \mathrm{~d}^{6}$ metal complex reported to date. Recent record ${ }^{3}$ MLCT lifetimes for isoelectronic $\mathrm{Fe}(\mathrm{II})$ complexes were 528 ps and 2.6 ns. ${ }^{1,108}$

The luminescence lifetimes of $\left[\mathrm{Cr}\left(\mathrm{L}^{\mathrm{pyr}}\right)_{3}\right]$ at $20^{\circ} \mathrm{C}$ follow an approximately bell-shaped trend related to the SPP scale (dotted trace in Figure $3 \mathrm{~b}$ ). Taking the $\tau_{\mathrm{avg}}$-value in cyclooctane as a reference point (green square in Figure $3 b$ ), the weighted average ${ }^{3}$ MLCT lifetime shortens both with decreasing SPP scale ( $n$-hexane, cyclohexane) and with increasing SPP scale ( $p$-xylene, toluene, di- $n$-butyl ether, 1,4dioxane). Thus, the photophysical properties of $\left[\mathrm{Cr}\left(\mathrm{L}^{\mathrm{pyr}}\right)_{3}\right]$ at $20^{\circ} \mathrm{C}$ seem to be optimal in deaerated cyclooctane, and under these conditions, the luminescence quantum yield $(\varphi)$ is $9 \times$ $10^{-4}$. This is a factor of 90 greater than the luminescence quantum yield of $10^{-5}$ previously determined for $\left[\mathrm{Cr}\left(\mathrm{L}^{\mathrm{H}}\right)_{3}\right] .{ }^{88}$ Evidently, the attachment of the pyrene unit to the diisocyanide ligand framework improves the luminescence quantum yield drastically despite a redshift of the emission by $1100 \mathrm{~cm}^{-1}$ for $\left[\mathrm{Cr}\left(\mathrm{L}^{\mathrm{pyr}}\right)_{3}\right]$ in cyclooctane relative to $\left[\mathrm{Cr}\left(\mathrm{L}^{\mathrm{H}}\right)_{3}\right]$ in THF. In $n$-hexane, $\varphi=3 \times 10^{-4}$ and in $p$-xylene, $\varphi=1 \times$ $10^{-4}$ for $\left[\mathrm{Cr}\left(\mathrm{L}^{\mathrm{pyr}}\right)_{3}\right]$, hence the luminescence quantum yields follow a similar trend as a function of solvent polarity as the ${ }^{3}$ MLCT lifetimes. Typically, a significant redshift of the emission is linked to a decrease of the luminescence quantum yield as a consequence of the energy gap law. ${ }^{47,50,55,109}$ Against this background, the factor-of- 90 improvement of the luminescence quantum yield of $\left[\mathrm{Cr}\left(\mathrm{L}^{\mathrm{pyr}}\right)_{3}\right]$ relative to $\left[\mathrm{Cr}\left(\mathrm{L}^{\mathrm{H}}\right)_{3}\right]$ in THF is all the more remarkable. In $p$-xylene, the quantum yield of $\left[\mathrm{Cr}\left(\mathrm{L}^{\mathrm{pyr}}\right)_{3}\right]$ is 1 order of magnitude larger than that for $\left[\mathrm{Cr}\left(\mathrm{L}^{\mathrm{H}}\right)_{3}\right]$ in THF despite a redshift of the emission by almost $2000 \mathrm{~cm}^{-1}$. 
Transient absorption (TA) spectroscopy reveals a ground state bleach (GSB) between 430 and $530 \mathrm{~nm}$ (Figure $2 \mathrm{~b}$, Figure 4c, Figure S28) coincident with the ${ }^{1} \mathrm{MLCT}$ absorption

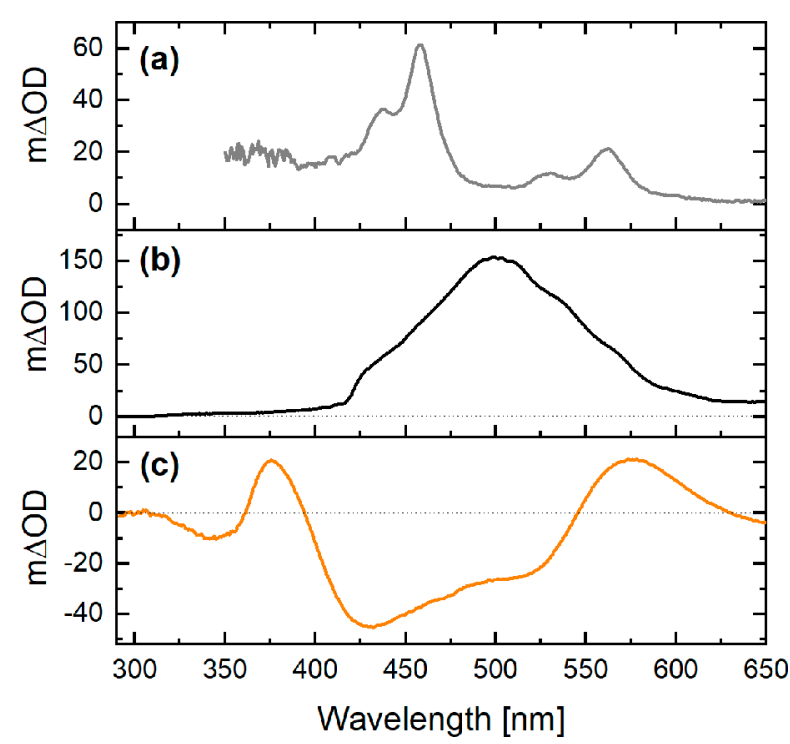

Figure 4. Sensitized triplet absorption spectra of (a) pyrene and (b) $\mathrm{L}^{\mathrm{pyr}}$ recorded after excitation of an iridium(III) triplet sensitizer at 450 $\mathrm{nm}$ and subsequent triplet-triplet energy transfer to pyrene or $\mathrm{L}^{\mathrm{pyr}}$; see SI page S31 for details). (c) Transient absorption spectrum of $\left[\mathrm{Cr}\left(\mathrm{L}^{\mathrm{pyr}}\right)_{3}\right]$ following excitation at $473 \mathrm{~nm}$ and time-integration over 3 ns immediately after excitation with pulses of ca. 30 ps duration. All spectra were recorded in deaerated toluene at $20{ }^{\circ} \mathrm{C}$.

bands (compare solid blue lines in Figure $2 a / b$ ). Furthermore, a weak GSB of the pyrene absorption is observed around 330 $\mathrm{nm}$ in Figure 2b/Figure 4c (compare to solid blue and gray traces in Figure $2 \mathrm{a}$ ), and there are excited state absorption (ESA) bands at 370 and $570 \mathrm{~nm}$. The GSB around $450 \mathrm{~nm}$ as well as the ESA bands at 370 and $570 \mathrm{~nm}$ are also seen for the $\left[\mathrm{Cr}\left(\mathrm{L}^{\mathrm{H}}\right)_{3}\right]$ parent complex, ${ }^{88}$ while the pyrene-related GSB bleach at $330 \mathrm{~nm}$ is unique to $\left[\mathrm{Cr}\left(\mathrm{L}^{\mathrm{pyr}}\right)_{3}\right]$. The ESA band at $370 \mathrm{~nm}$ has been previously attributed to the one-electron reduced diisocyanide ligand, ${ }^{88,94,96,107}$ and is reminiscent of an analogous TA feature observable for the ${ }^{3} \mathrm{MLCT}$ excited state of $\left[\mathrm{Ru}(\mathrm{bpy})_{3}\right]^{2+} \cdot{ }^{110}$ The ground state bleach recoveries at 430 and $330 \mathrm{~nm}$ as well as the decays of the ESA band at $570 \mathrm{~nm}$ follow identical kinetics in all solvents within experimental accuracy, and furthermore these transient absorption signals exhibit identical decay behavior as the ${ }^{3} \mathrm{MLCT}$ luminescence in any given solvent (Figures 2a and S29).

Since the TA spectra of $\left[\mathrm{Cr}\left(\mathrm{L}^{\mathrm{pyr}}\right)_{3}\right]$ are dominated by a GSB, they are comparatively independent of solvent (Figure S28), and most importantly, they do not show the diagnostic absorption bands associated with the lowest triplet excited state of pyrene (Figure 4a). Specifically, neither the characteristic absorption band of unsubstituted (commercial) tripletexcited pyrene at $458 \mathrm{~nm}$ (Figure $4 \mathrm{a}$ ) nor the broader feature of triplet-excited $\mathrm{L}^{\mathrm{pyr}}$ at $500 \mathrm{~nm}$ (Figure $4 \mathrm{~b}$ ) are present in the TA spectrum of $\left[\mathrm{Cr}\left(\mathrm{L}^{\mathrm{pyr}}\right)_{3}\right]$ (Figure $4 \mathrm{c}$ and Figure S28). Evidently, an isolated ${ }^{3} \mathrm{LC}$ state on the pyrene moiety is not populated upon excitation, indicating that $\left[\mathrm{Cr}\left(\mathrm{L}^{\mathrm{pyr}}\right)_{3}\right]$ does not show any triplet reservoir effect behavior. The weak GSB at $330 \mathrm{~nm}$ (Figures $2 \mathrm{~b}, 4 \mathrm{c}$, and S28), coinciding with the pyrene ground state absorption (Figure $2 \mathrm{a}$ ), suggests that the pyrene moiety is involved to some non-negligible extent in the emissive excited state of $\left[\mathrm{Cr}\left(\mathrm{L}^{\mathrm{pyr}}\right)_{3}\right]$. These combined observations together with the identical kinetic profiles of the TA and emission data (Figure S29) indicate that there is a single photoactive excited state in $\left[\mathrm{Cr}\left(\mathrm{L}^{\mathrm{pyr}}\right)_{3}\right]$, which largely has similar character as the ${ }^{3} \mathrm{MLCT}$ state of $\left[\mathrm{Cr}\left(\mathrm{L}^{\mathrm{H}}\right)_{3}\right]$ but with some admixed ${ }^{3} *$ pyrene character (hence the minor bleach at $330 \mathrm{~nm}$ ). In other words, the luminescent excited state of $\left[\mathrm{Cr}\left(\mathrm{L}^{\mathrm{pyr}}\right)_{3}\right]$ seems to be a ${ }^{3} \mathrm{MLCT}$ state in which the excited electron is delocalized over a large portion of the diisocyanide ligand framework including to some extent the pyrene moiety. In the electronic ground state, a noncoplanar arrangement between the pyrene moieties and the central ring of the $m$-terphenyl backbone is evident from the NMR experiments (Figure 1), leading to electronic decoupling, which is in line with the observation that the UV-vis spectrum of $\left[\mathrm{Cr}\left(\mathrm{L}^{\mathrm{pyr}}\right)_{3}\right]$ is essentially equal to the sum of $\mathrm{UV}-\mathrm{vis}$ absorption spectra of its individual components (Figure $2 \mathrm{a}$ and Figure S19). By contrast, in the photoactive excited state the pyrene unit can possibly adopt a more coplanar arrangement to the diisocyanide framework (Scheme S4), similar to what has previously been reported for aryl-substituted $\left[\mathrm{Ru}(\mathrm{bpy})_{3}\right]^{2+}$ derivatives. $^{53,111}$ Specifically, it was previously found that peripheral aryl-substituents became more coplanar with the bpy core upon excitation to the MLCT state, thereby allowing for greater electron delocalization over the entire $\pi$-system of the aryl-substituted ligands. Against this background, it seems plausible that a similar coplanarization between the pyrene subunits and the diisocyanide backbone plays a key role in photoexcited $\left[\mathrm{Cr}\left(\mathrm{L}^{\mathrm{pyr}}\right)_{3}\right]$ and leads to the strongly enhanced MLCT lifetimes and luminescence quantum yields when compared to $\left[\mathrm{Cr}\left(\mathrm{L}^{\mathrm{H}}\right)_{3}\right]$. Corroborating, the triplet absorption spectrum of the free $L^{\text {pyr }}$ ligand does not resemble that of free pyrene (compare Figures $4 \mathrm{a}$ and $4 \mathrm{~b}$ ) indicating that the attachment of pyrene in the backbone of $\mathrm{L}^{\mathrm{H}}$ does indeed result in a non-negligible electronic coupling between the pyrene moiety and the diisocyanide framework in the lowest triplet excited state.

Furthermore, the strong emission solvatochromism observed for $\left[\mathrm{Cr}\left(\mathrm{L}^{\mathrm{pyr}}\right)_{3}\right]$ (Figure 3a) seems fully compatible with the interpretation of a more strongly delocalized ${ }^{3} \mathrm{MLCT}$ state likely featuring a greater dipole moment relative to $\left[\mathrm{Cr}\left(\mathrm{L}^{\mathrm{H}}\right)_{3}\right]$. The position of pyrene, extending away from the $\mathrm{Cr}^{0}$ center, means that any delocalization of the MLCT-excited electron over $\mathrm{L}^{\mathrm{pyr}}$ necessarily will occur along the transition dipole moment axis, leading to a larger change in dipole moment. Previous studies of ruthenium(II) diimine complexes with extended $\pi$-systems exhibiting large solvatochromism did not seem to address this specific orientation aspect, ${ }^{52,112}$ but a study of two ruthenium(II)-bpy complexes with phenylethylene substituents in either 4,4' or $5,5^{\prime}$ positions concluded that the electronic delocalization into the phenylethylene substituents in the $4,4^{\prime}$-substituted complex was greater, leading to faster radiative decay. ${ }^{53,55}$ Moreover, several other ruthenium(II) and iron(II) diimine systems have exhibited pronounced absorption and/or emission solvatochromism, but in these cases this was more strongly related to (solvent) hydrogen-bonding effects than solvent polarity. ${ }^{45,64,113-116}$

Turning back to the approximately bell-shaped dependence of ${ }^{3}$ MLCT luminescence lifetimes on the SPP scale in Figure $3 \mathrm{~b}$, we note that the decrease of lifetimes with increasing solvent polarity goes hand in hand with a decrease of the ${ }^{3}$ MLCT energy (caused by better stabilization of the chargeredistribution in more polar solvents), as predicted by the 
energy gap law. ${ }^{117}$ In other words, the smaller the energy gap between the emissive ${ }^{3} \mathrm{MLCT}$ and the electronic ground state gets (compare the black and red ${ }^{3}$ MLCT parabola in Figure $5 b)$, the faster nonradiative excited-state relaxation directly to

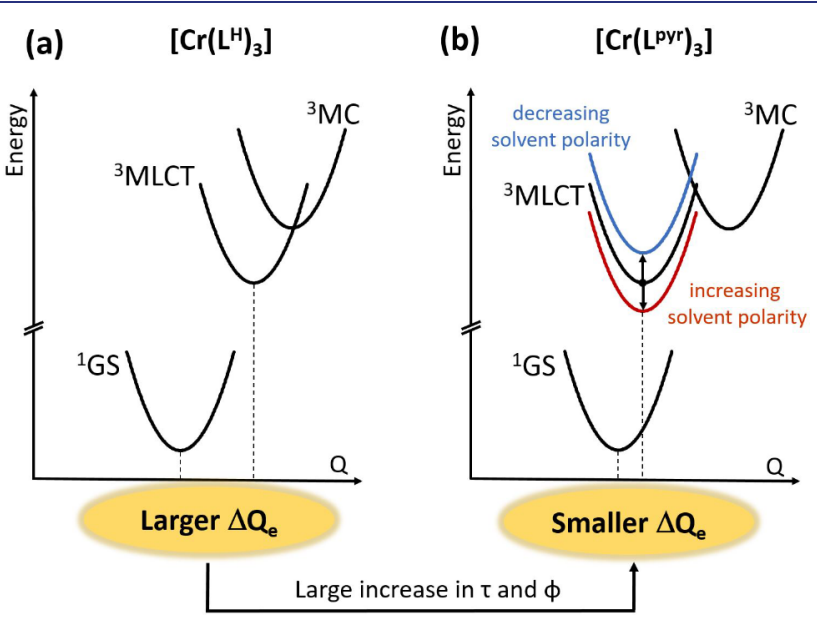

Figure 5. Single configurational coordinate ("potential well") diagrams for $(\mathrm{a})\left[\mathrm{Cr}\left(\mathrm{L}^{\mathrm{H}}\right)_{3}\right]$ and $(\mathrm{b})\left[\mathrm{Cr}\left(\mathrm{L}^{\mathrm{pyr}}\right)_{3}\right]$. Colored potential wells in part $b$ illustrate the effects of different solvents on the ${ }^{3} \mathrm{MLCT}$ state.

the ground state $\left({ }^{1} \mathrm{GS}\right)$ becomes, hereby resulting in decreasing luminescence lifetimes with increasing solvent polarity from cyclooctane onward to 1,4-dioxane. However, the energy gap law fails to explain the observable ${ }^{3} \mathrm{MLCT}$ lifetime decrease from cyclooctane $\left(\tau_{\text {avg }}=6.10 \mathrm{~ns}\right)$ to cyclohexane $\left(\tau_{\text {avg }}=4.06 \mathrm{~ns}\right)$ and $n$-hexane $\left(\tau_{\text {avg }}=2.82 \mathrm{~ns}\right)$, hence a different phenomenon must be at work in this case. In the following we discuss the possibility that a ${ }^{3} \mathrm{MC}$ state becomes a key contributor to the excited-state decay behavior in this solvent polarity regime.

As noted in the introduction, the ligand field in $3 \mathrm{~d}^{6}$ metal complexes is comparatively weak and MC excited states are known to be energetically close to the lowest ${ }^{3} \mathrm{MLCT}$ state in $\mathrm{Fe}$ (II) compounds. ${ }^{42,46,118-122}$ An analogous scenario is likely encountered for our isoelectronic $\mathrm{Cr}^{0}$ complexes from Scheme $1{ }^{89}$ In particular, a triplet MC state (labeled ${ }^{3} \mathrm{MC}$ in Figure 5a) was expected to be energetically close to the emissive ${ }^{3}$ MLCT state of the $\left[\mathrm{Cr}\left(\mathrm{L}^{\mathrm{H}}\right)_{3}\right]$ parent complex, ${ }^{88}$ and this is also the case for the new pyrene-decorated variant $\left[\mathrm{Cr}\left(\mathrm{L}^{\mathrm{pyr}}\right)_{3}\right]$ (Figure $5 \mathrm{~b}$ ). Corroborating, thermal population of the ${ }^{3} \mathrm{MC}$ state from the ${ }^{3} \mathrm{MLCT}$ state represents a significant nonradiative excited-state deactivation pathway in a related $\mathrm{Mo}^{0}$ complex, ${ }^{96}$ and furthermore this is a well-known deactivation process for isoelectronic $\mathrm{Ru}(\mathrm{II}) \alpha$-diimines. ${ }^{123}$ Depending on the barrier height for internal conversion from the ${ }^{3}$ MLCT to the ${ }^{3} \mathrm{MC}$ state, the rate of nonradiative excited-state deactivation in $\left[\mathrm{Cr}\left(\mathrm{L}^{\mathrm{pyr}}\right)_{3}\right]$ can therefore be expected to vary significantly. Indeed, temperature-dependent luminescence lifetimes studies of $\left[\mathrm{Cr}\left(\mathrm{L}^{\mathrm{pyr}}\right)_{3}\right]$ in $n$-hexane and cyclooctane (Figures S33a/b and Table S2) and an Arrhenius-type analysis of $\tau_{\mathrm{avg}}{ }^{-1}$ values versus inverse temperature (Figure S33c) indicate that the barriers for excited-state deactivation in these two solvents are significantly different. Specifically, we find barriers of $23.0 \mathrm{~kJ} / \mathrm{mol}$ for $n$-hexane and $28.3 \mathrm{~kJ} / \mathrm{mol}$ for cyclooctane, suggesting that the ${ }^{3} \mathrm{MLCT}-{ }^{3} \mathrm{MC}$ crossover rate is indeed larger in the more apolar $n$-hexane than in the relatively less apolar cyclooctane.
The ${ }^{3}$ MLCT emission band changes only very weakly between the solvents $n$-hexane, cyclohexane, and cyclooctane (Figure 3a), indicating that the view of ${ }^{3} \mathrm{MLCT}$ potential well shifting to higher energies (compare the black and blue ${ }^{3}$ MLCT parabola in Figure $5 b$ ) is overly simplistic. From the single configurational coordinate diagram in Figure $5 b$, it is obvious that the barrier for internal conversion from ${ }^{3} \mathrm{MLCT}$ to ${ }^{3} \mathrm{MC}$ also depends strongly on eventual displacements of the two relevant potential wells along the nuclear coordinate $\mathrm{Q}$. The latter comprises an ensemble of molecular distortions that accompany the electron redistribution in the individual electronic states, and their individual contributions are tricky to elucidate as long as the emission bands do not exhibit wellresolved vibrational fine structure. For unstructured MLCT luminescence bands, their full width at half-maximum (fwhm) can be used as a proxy to compare the relative magnitudes of changes along the collective nuclear coordinate $(\Delta \mathrm{Q})$ between structurally related compounds. It is conceivable that even subtle changes in the equilibrium distortions $\left(\Delta \mathrm{Q}_{e}\right)$ of the ${ }^{3} \mathrm{MLCT}$ and ${ }^{3} \mathrm{MC}$ potentials as a function of solvent can have a significant impact on the barrier height for internal conversion, and consequently on nonradiative relaxation via the ${ }^{3} \mathrm{MC}$ state. Similarly, even small changes of force constants and subtle variations in the extent of anharmonicity of the relevant potential wells upon solvent change can affect that internal conversion significantly. In this context it is interesting to note that recent work on $\mathrm{Fe}$ (II) tetracyano-polypyridyl complexes reported that ${ }^{3} \mathrm{MLCT}$ lifetimes vary in nonmonotonical fashion when the ${ }^{3} \mathrm{MLCT}$ energy is changed by solvent variation. ${ }^{46}$ This was attributed to competing ${ }^{3}$ MLCT deactivation pathways involving direct relaxation to the ground state and indirect relaxation via the ${ }^{3} \mathrm{MC}$ state, in complete analogy to our line of arguments put forward above.

Leaving the solvent dependence discussion in $\left[\mathrm{Cr}\left(\mathrm{L}^{\mathrm{pyr}}\right)_{3}\right]$ behind and turning back to the comparison of photophysical properties of $\left[\mathrm{Cr}\left(\mathrm{L}^{\mathrm{pyr}}\right)_{3}\right]$ and $\left[\mathrm{Cr}\left(\mathrm{L}^{\mathrm{H}}\right)_{3}\right]$, it is useful to compare the ${ }^{3}$ MLCT emission band widths of these two compounds. For $\left[\mathrm{Cr}\left(\mathrm{L}^{\mathrm{H}}\right)_{3}\right]$, the pertinent fwhm is $3200 \mathrm{~cm}^{-1}$ while for $\left[\mathrm{Cr}\left(\mathrm{L}^{\mathrm{pyr}}\right)_{3}\right]$, it amounts to only about $2600 \mathrm{~cm}^{-1}$ (Figure S20), indicating that the average displacement along the nuclear coordinate $\mathrm{Q}$ in the ${ }^{3} \mathrm{MLCT}$ state relative to the ground state $\left({ }^{1} \mathrm{GS}\right.$ in Figure 5) is smaller in the new pyrene-decorated complex than that in the $\left[\mathrm{Cr}\left(\mathrm{L}^{\mathrm{H}}\right)_{3}\right]$ parent compound (yellow shaded labels in Figure 5). This finding is in line with previous reports of ruthenium(II) diimine complexes which have also found that more extended $\pi$-systems cause weaker ${ }^{3} \mathrm{MLCT}$ distortions. $^{47-54}$ Thus, the smaller $\Delta \mathrm{Q}_{\boldsymbol{e}}$ for $\left[\mathrm{Cr}\left(\mathrm{L}^{\mathrm{pyr}}\right)_{3}\right]$ likely results in relatively less efficient deactivation through $\mathrm{MC}$ states than that in the case of $\left[\mathrm{Cr}\left(\mathrm{L}^{\mathrm{H}}\right)_{3}\right]$, leading to overall improved luminescence properties for $\left[\mathrm{Cr}\left(\mathrm{L}^{\mathrm{pyr}}\right)_{3}\right]$ including a new record ${ }^{3} \mathrm{MLCT}$ excited-state lifetime and photoluminescence quantum yield among $3 \mathrm{~d}^{6}$ metal complexes in solution at room temperature.

\section{CONCLUSION}

Incorporation of pyrene into the backbone of a chromium(0) tris(diisocyanide) complex gave access to the brightest $3 \mathrm{~d}^{6}$ MLCT emitter known so far. While electronically decoupled in the ground state according to in-depth NMR experiments, the pyrene units appear to be involved in the emissive ${ }^{3}$ MLCT excited state, permitting electron delocalization over a large portion of the $\pi$-conjugated framework of the ligands. This 
delocalization of the MLCT-excited electron leads to a comparatively weak excited-state distortion, which decelerates undesired nonradiative relaxation processes. Consequently, $\left[\mathrm{Cr}\left(\mathrm{L}^{\mathrm{pyr}}\right)_{3}\right]$ exhibits a luminescence quantum yield $\left(9 \times 10^{-4}\right)$ that is nearly 2 orders of magnitude greater than that of the previously investigated parent complex $\left[\mathrm{Cr}\left(\mathrm{L}^{\mathrm{H}}\right)_{3}\right]$ lacking pyrene decoration. Considering that the pyrene-decoration entails a substantial redshift of the emissive ${ }^{3} \mathrm{MLCT}$ state (1100-2000 $\mathrm{cm}^{-1}$ depending on solvent), the strongly enhanced luminescence of $\left[\mathrm{Cr}\left(\mathrm{L}^{\mathrm{pyr}}\right)_{3}\right]$ is all the more remarkable.

$\left[\mathrm{Cr}\left(\mathrm{L}^{\mathrm{pyr}}\right)_{3}\right]$ demonstrates a notable emission solvatochromism, suggesting that luminescence from the more strongly delocalized MLCT state of $\left[\mathrm{Cr}\left(\mathrm{L}^{\mathrm{pyr}}\right)_{3}\right]$ is associated with a larger change in dipole moment than that in the case of the parent $\left[\mathrm{Cr}\left(\mathrm{L}^{\mathrm{H}}\right)_{3}\right]$ complex, which exhibits weaker delocalization of the MLCT-excited electron. An unusual bell-shaped dependence of ${ }^{3} \mathrm{MLCT}$ luminescence lifetimes on solvent polarity is observable, likely caused by two counteracting effects that have also been invoked lately to account for the uncommon solvent dependence of ${ }^{3}$ MLCT lifetimes of an iron(II) compound: ${ }^{46}$ (i) decreased solvent polarity increases the ${ }^{3}$ MLCT energy and decelerates direct nonradiative relaxation to the ground state and (ii) the higher the ${ }^{3} \mathrm{MLCT}$ energy becomes, the more facile the population of nearby ${ }^{3} \mathrm{MC}$ states seems to become, and thereby, nonradiative relaxation via those states is likely accelerated. Solvent variation therefore allowed us to find the sweet-spot between predominant deactivation through that presumed ${ }^{3} \mathrm{MC}$ deactivation pathway (most apolar solvents) and direct relaxation to the electronic ground state (polar solvents). In deaerated cyclooctane at $20{ }^{\circ} \mathrm{C}, \tau_{\text {avg }}=6.10 \mathrm{~ns}$, which is, to the best of our knowledge, the longest ${ }^{3} \mathrm{MLCT}$ lifetime for any $3 \mathrm{~d}^{6}$ metal complex in solution at room temperature reported to date. ${ }^{1,6,108}$

The MLCT delocalization effect exploited here for [Cr$\left.\left[\mathrm{L}^{\mathrm{pyr}}\right)_{3}\right]$ is well explored in precious metal-based $4 \mathrm{~d}^{6}$ and $5 \mathrm{~d}^{6}$ complexes. ${ }^{47-54}$ Our work demonstrates that this concept is to some extent applicable to $3 \mathrm{~d}^{6}$ metal complexes, but their smaller ligand field splitting leads to unusual behavior, such as, for example, the bell-shaped dependence of excited-state lifetimes on solvent polarity. This resonates with recent studies, which found that there are both analogies but also very clear differences between the photophysics of precious metal complexes and their congeners made from earthabundant transition metals. ${ }^{20,34,124-126}$ The aim to develop photoactive complexes with cheap and abundant base metals is of course highly attractive from an economic and sustainability point of view, but at present, the photophysics and the photochemistry of such complexes yet remain underdeveloped compared to precious metal-based compounds; hence, there is still much need for fundamental research in this field.

\section{ASSOCIATED CONTENT}

\section{S1 Supporting Information}

The Supporting Information is available free of charge at https://pubs.acs.org/doi/10.1021/jacs.1c07345.

Synthetic protocols and characterization data, description of equipment and methods as well as supplementary spectroscopic data (PDF)

\section{AUTHOR INFORMATION}

\section{Corresponding Author}

Oliver S. Wenger - Department of Chemistry, University of Basel, 4056 Basel, Switzerland; (1) orcid.org/0000-0002-

0739-0553; Email: oliver.wenger@unibas.ch

\section{Authors}

Christina Wegeberg - Department of Chemistry, University of Basel, 4056 Basel, Switzerland; ㅇo이.org/0000-00026034-453X

Daniel Häussinger - Department of Chemistry, University of Basel, 4056 Basel, Switzerland; (1) orcid.org/0000-00024798-0072

Complete contact information is available at: https://pubs.acs.org/10.1021/jacs.1c07345

\section{Notes}

The authors declare no competing financial interest.

\section{ACKNOWLEDGMENTS}

C.W. thanks the Independent Research Fund Denmark for an international postdoctoral grant (9059-00003B). O.S.W. acknowledges funding from the Swiss National Science Foundation through grants number 200021_178760 and 206021_157687. Dr. Christopher B. Larsen is acknowledged for valuable input.

\section{REFERENCES}

(1) Braun, J. D.; Lozada, I. B.; Kolodziej, C.; Burda, C.; Newman, K. M. E.; van Lierop, J.; Davis, R. L.; Herbert, D. E. Iron(II) Coordination Complexes with Panchromatic Absorption and Nanosecond Charge-Transfer Excited State Lifetimes. Nat. Chem. 2019, 11, $1144-1150$.

(2) Kjær, K. S.; Kaul, N.; Prakash, O.; Chábera, P.; Rosemann, N. W.; Honarfar, A.; Gordivska, O.; Fredin, L. A.; Bergquist, K.-E.; Häggström, L.; Ericsson, T.; Lindh, L.; Yartsev, A.; Styring, S.; Huang, P.; Uhlig, J.; Bendix, J.; Strand, D.; Sundström, V.; Persson, P.; Lomoth, R.; Wärnmark, K. Luminescence and Reactivity of a ChargeTransfer Excited Iron Complex with Nanosecond Lifetime. Science 2019, 363, 249-253.

(3) Liu, Y.; Harlang, T.; Canton, S. E.; Chábera, P.; SuárezAlcántara, K.; Fleckhaus, A.; Vithanage, D. A.; Göransson, E.; Corani, A.; Lomoth, R.; Sundström, V.; Wärnmark, K. Towards Longer-Lived Metal-to-Ligand Charge Transfer States of Iron(II) Complexes: An $N$-heterocyclic Carbene Approach. Chem. Commun. 2013, 49, 64126414.

(4) Chábera, P.; Liu, Y.; Prakash, O.; Thyrhaug, E.; Nahhas, A. E.; Honarfar, A.; Essén, S.; Fredin, L. A.; Harlang, T. C. B.; Kjær, K. S.; Handrup, K.; Ericson, F.; Tatsuno, H.; Morgan, K.; Schnadt, J.; Häggström, L.; Ericsson, T.; Sobkowiak, A.; Lidin, S.; Huang, P.; Styring, S.; Uhlig, J.; Bendix, J.; Lomoth, R.; Sundström, V.; Persson, P.; Wärnmark, K. A Low-Spin Fe(III) Complex with 100-ps Ligandto-Metal Charge Transfer Photoluminescence. Nature 2017, 543, 695-699.

(5) Duchanois, T.; Liu, L.; Pastore, M.; Monari, A.; Cebrián, C.; Trolez, Y.; Darari, M.; Magra, K.; Francés-Monerris, A.; Domenichini, E.; Beley, M.; Assfeld, X.; Haacke, S.; Gros, P. NHC-Based Iron Sensitizers for DSSCs. Inorganics 2018, 6, 63.

(6) Liu, L.; Duchanois, T.; Etienne, T.; Monari, A.; Beley, M.; Assfeld, X.; Haacke, S.; Gros, P. C. A New Record Excited State ${ }^{3}$ MLCT Lifetime for Metalorganic Iron(II) Complexes. Phys. Chem. Chem. Phys. 2016, 18, 12550-12556.

(7) Harlang, T. C. B.; Liu, Y.; Gordivska, O.; Fredin, L. A.; Ponseca, C. S.; Huang, P.; Chábera, P.; Kjaer, K. S.; Mateos, H.; Uhlig, J.; Lomoth, R.; Wallenberg, R.; Styring, S.; Persson, P.; Sundström, V.; 
Wärnmark, K. Iron Sensitizer Converts Light to Electrons with $92 \%$ Yield. Nat. Chem. 2015, 7, 883-889.

(8) Zhang, K.; Ash, R.; Girolami, G. S.; Vura-Weis, J. Tracking the Metal-Centered Triplet in Photoinduced Spin Crossover of $\mathrm{Fe}$ (phen) ${ }_{3}^{2+}$ with Tabletop Femtosecond M-Edge X-ray Absorption Near-Edge Structure Spectroscopy. J. Am. Chem. Soc. 2019, 141, 17180-17188.

(9) Young, E. R.; Oldacre, A. Iron Hits the Mark. Science 2019, 363, 225-226.

(10) Hamze, R.; Peltier, J. L.; Sylvinson, D.; Jung, M.; Cardenas, J.; Haiges, R.; Soleilhavoup, M.; Jazzar, R.; Djurovich, P. I.; Bertrand, G.; Thompson, M. E. Eliminating Nonradiative Decay in $\mathrm{Cu}(\mathrm{I})$ Emitters: $>$ 99\% Quantum Efficiency and Microsecond Lifetime. Science 2019, $363,601-606$.

(11) Di, D.; Romanov, A. S.; Yang, L.; Richter, J. M.; Rivett, J. P. H.; Jones, S.; Thomas, T. H.; Abdi Jalebi, M.; Friend, R. H.; Linnolahti, M.; Bochmann, M.; Credgington, D. High-Performance LightEmitting Diodes based on Carbene-Metal-Amides. Science 2017, 356, 159-163.

(12) Gernert, M.; Balles-Wolf, L.; Kerner, F.; Müller, U.; Schmiedel, A.; Holzapfel, M.; Marian, C. M.; Pflaum, J.; Lambert, C.; Steffen, A. Cyclic (Amino)(aryl)carbenes Enter the Field of Chromophore Ligands: Expanded $\pi$ System Leads to Unusually Deep Red Emitting $\mathrm{Cu}^{\mathrm{I}}$ Compounds. J. Am. Chem. Soc. 2020, 142, 8897-8909.

(13) Housecroft, C. E.; Constable, E. C. The Emergence of Copper(I)-based Dye Sensitized Solar Cells. Chem. Soc. Rev. 2015, 44, 8386-8398.

(14) Lazorski, M. S.; Castellano, F. N. Advances in the Light Conversion Properties of $\mathrm{Cu}(\mathrm{I})$-based Photosensitizers. Polyhedron 2014, 82, 57-70.

(15) Hossain, A.; Bhattacharyya, A.; Reiser, O. Copper's Rapid Ascent in Visible-light Photoredox Catalysis. Science 2019, 364, No. eaav9713.

(16) Tellis, J. C.; Primer, D. N.; Molander, G. A. Single-Electron Transmetalation in Organoboron Cross-coupling by Photoredox/ Nickel Dual Catalysis. Science 2014, 345, 433-436.

(17) Shields, B. J.; Kudisch, B.; Scholes, G. D.; Doyle, A. G. LongLived Charge-Transfer States of Nickel(II) Aryl Halide Complexes Facilitate Bimolecular Photoinduced Electron Transfer. J. Am. Chem. Soc. 2018, 140, 3035-3039.

(18) Milligan, J. A.; Phelan, J. P.; Badir, S. O.; Molander, G. A. Alkyl Carbon-Carbon Bond Formation by Nickel/Photoredox CrossCoupling. Angew. Chem., Int. Ed. 2019, 58, 6152-6163.

(19) Ting, S. I.; Garakyaraghi, S.; Taliaferro, C. M.; Shields, B. J.; Scholes, G. D.; Castellano, F. N.; Doyle, A. G. ${ }^{3}$ d-d Excited States of $\mathrm{Ni}$ (II) Complexes Relevant to Photoredox Catalysis: Spectroscopic Identification and Mechanistic Implications. J. Am. Chem. Soc. 2020, 142, 5800-5810.

(20) Wong, Y.-S.; Tang, M.-C.; Ng, M.; Yam, V. W.-W. Toward the Design of Phosphorescent Emitters of Cyclometalated EarthAbundant Nickel(II) and Their Supramolecular Study. J. Am. Chem. Soc. 2020, 142, 7638-7646.

(21) Welin, E. R.; Le, C.; Arias-Rotondo, D. M.; McCusker, J. K.; MacMillan, D. W. C. Photosensitized, Energy Transfer-mediated Organometallic Catalysis through Electronically Excited Nickel(II). Science 2017, 355, 380-385.

(22) Otto, S.; Dorn, M.; Förster, C.; Bauer, M.; Seitz, M.; Heinze, K. Understanding and Exploiting Long-Lived Near-Infrared Emission of a Molecular Ruby. Coord. Chem. Rev. 2018, 359, 102-111.

(23) Treiling, S.; Wang, C.; Förster, C.; Reichenauer, F.; Kalmbach, J.; Boden, P.; Harris, J. P.; Carrella, L. M.; Rentschler, E.; ReschGenger, U.; Reber, C.; Seitz, M.; Gerhards, M.; Heinze, K. Luminescence and Light-Driven Energy and Electron Transfer from an Exceptionally Long-Lived Excited State of a Non-Innocent Chromium(III) Complex. Angew. Chem. 2019, 131, 18243-18253.

(24) Jiménez, J.-R.; Doistau, B.; Cruz, C. M.; Besnard, C.; Cuerva, J. M.; Campaña, A. G.; Piguet, C. Chiral Molecular Ruby $\left[\mathrm{Cr}(\mathrm{dqp})_{2}\right]^{3+}$ with Long-Lived Circularly Polarized Luminescence. J. Am. Chem. Soc. 2019, 141, 13244-13252.
(25) Stevenson, S. M.; Shores, M. P.; Ferreira, E. M. Photooxidizing Chromium Catalysts for Promoting Radical Cation Cycloadditions. Angew. Chem., Int. Ed. 2015, 54, 6506-6510.

(26) Olafsen, B. E.; Crescenzo, G. V.; Moisey, L. P.; Patrick, B. O.; Smith, K. M. Photolytic Reactivity of Organometallic Chromium Bipyridine Complexes. Inorg. Chem. 2018, 57, 9611-9621.

(27) Neuman, D.; Ostrowski, A. D.; Mikhailovsky, A. A.; Absalonson, R. O.; Strouse, G. F.; Ford, P. C. Quantum Dot Fluorescence Quenching Pathways with $\mathrm{Cr}$ (III) Complexes. Photosensitized NO Production from trans-Cr $($ cyclam $)(\mathrm{ONO})_{2}{ }^{+}$. J. Am. Chem. Soc. 2008, 130, 168-175.

(28) Sinha, N.; Jiménez, J.-R.; Pfund, B.; Prescimone, A.; Piguet, C.; Wenger, O. S. A near-infrared-II emissive chromium(III) complex. Angew. Chem., Int. Ed. 2021, DOI: 10.1002/anie.202106398.

(29) Wenger, O. S. Photoactive Complexes with Earth-Abundant Metals. J. Am. Chem. Soc. 2018, 140, 13522-13533.

(30) Wenger, O. S. Is Iron the New Ruthenium? Chem. - Eur. J. 2019, 25, 6043-6052.

(31) Chen, J.; Browne, W. R. Photochemistry of Iron Complexes. Coord. Chem. Rev. 2018, 374, 15-35.

(32) Wenger, O. S. Photoactive nickel complexes in cross-coupling catalysis. Chem. - Eur. J. 2021, 27, 2270-2278.

(33) Pal, A. K.; Li, C.; Hanan, G. S.; Zysman-Colman, E. BlueEmissive Cobalt(III) Complexes and Their Use in the Photocatalytic Trifluoromethylation of Polycyclic Aromatic Hydrocarbons. Angew. Chem., Int. Ed. 2018, 57, 8027-8031.

(34) Zhang, Y.; Lee, T. S.; Favale, J. M.; Leary, D. C.; Petersen, J. L.; Scholes, G. D.; Castellano, F. N.; Milsmann, C. Delayed Fluorescence from a Zirconium(IV) Photosensitizer with Ligand-to-Metal ChargeTransfer Excited States. Nat. Chem. 2020, 12, 345-352.

(35) Kaufhold, S.; Rosemann, N. W.; Chábera, P.; Lindh, L.; Bolaño Losada, I.; Uhlig, J.; Pascher, T.; Strand, D.; Wärnmark, K.; Yartsev, A.; Persson, P. Microsecond Photoluminescence and Photoreactivity of a Metal-Centered Excited State in a Hexacarbene-Co(III) Complex. J. Am. Chem. Soc. 2021, 143, 1307-1312.

(36) Hockin, B. M.; Li, C.; Robertson, N.; Zysman-Colman, E. Photoredox Catalysts Based on Earth-Abundant Metal Complexes. Catal. Sci. Technol. 2019, 9, 889-915.

(37) Förster, C.; Heinze, K. Photophysics and photochemistry with Earth-abundant metals - fundamentals and concepts. Chem. Soc. Rev. 2020, 49, 1057-1070.

(38) Bizzarri, C.; Spuling, E.; Knoll, D. M.; Volz, D.; Bräse, S. Sustainable metal complexes for organic light-emitting diodes (OLEDs). Coord. Chem. Rev. 2018, 373, 49-82.

(39) McCusker, J. K. Electronic Structure in the Transition Metal Block and its Implications for Light Harvesting. Science 2019, 363, 484-488.

(40) Balzani, V.; Bergamini, G.; Marchioni, F.; Ceroni, P. Ru(II)bipyridine Complexes in Supramolecular Systems, Devices and Machines. Coord. Chem. Rev. 2006, 250, 1254-1266.

(41) McClanahan, S. F.; Kincaid, J. R. ${ }^{3}$ MLCT Lifetimes of Tris(2,2'-bipyridine)ruthenium(II). Position-Dependent Deuterium Effects. J. Am. Chem. Soc. 1986, 108, 3840-3841.

(42) Gawelda, W.; Cannizzo, A.; Pham, V.-T.; van Mourik, F.; Bressler, C.; Chergui, M. Ultrafast Nonadiabatic Dynamics of $\left[\mathrm{Fe}^{\mathrm{II}}(\mathrm{bpy})_{3}\right]^{2+}$ in solution. J. Am. Chem. Soc. 2007, 129, 8199-8206.

(43) Auböck, G.; Chergui, M. Sub-50-fs Photoinduced Spin Crossover in $\left[\mathrm{Fe}(\text { bpy })_{3}\right]^{2+}$. Nat. Chem. 2015, 7, 629-633.

(44) Jamula, L. L.; Brown, A. M.; Guo, D.; McCusker, J. K. Synthesis and Characterization of a High-Symmetry Ferrous Polypyridyl Complex: Approaching the ${ }^{5} \mathrm{~T}_{2} /{ }^{3} \mathrm{~T}_{1}$ Crossing Point for $\mathrm{Fe}^{\mathrm{II}}$. Inorg. Chem. 2014, 53, 15-17.

(45) Zhang, W.; Kjær, K. S.; Alonso-Mori, R.; Bergmann, U.; Chollet, M.; Fredin, L. A.; Hadt, R. G.; Hartsock, R. W.; Harlang, T.; Kroll, T.; Kubiček, K.; Lemke, H. T.; Liang, H. W.; Liu, Y.; Nielsen, M. M.; Persson, P.; Robinson, J. S.; Solomon, E. I.; Sun, Z.; Sokaras, D.; van Driel, T. B.; Weng, T.-C.; Zhu, D.; Wärnmark, K.; Sundström, V.; Gaffney, K. J. Manipulating Charge Transfer Excited State 
Relaxation and Spin Crossover in Iron Coordination Complexes with Ligand Substitution. Chem. Sci. 2017, 8, 515-523.

(46) Kunnus, K.; Li, L.; Titus, C. J.; Lee, S. J.; Reinhard, M. E.; Koroidov, S.; Kjær, K. S.; Hong, K.; Ledbetter, K.; Doriese, W. B.; O’Neil, G. C.; Swetz, D. S.; Ullom, J. N.; Li, D.; Irwin, K.; Nordlund, D.; Cordones, A. A.; Gaffney, K. J. Chemical Control of Competing Electron Transfer Pathways in Iron Tetracyano-Polypyridyl Photosensitizers. Chem. Sci. 2020, 11, 4360-4373.

(47) Strouse, G. F.; Schoonover, J. R.; Duesing, R.; Boyde, S.; Jones, W. E. J.; Meyer, T. J. Influence of Electronic Delocalization In Metalto-Ligand Charge Transfer Excited States. Inorg. Chem. 1995, 34, 473-487.

(48) Treadway, J. A.; Loeb, B.; Lopez, R.; Anderson, P. A.; Keene, F. R.; Meyer, T. J. Effect of Delocalization and Rigidity in the Acceptor Ligand on MLCT Excited-State Decay. Inorg. Chem. 1996, 35, 22422246.

(49) Treadway, J. A.; Strouse, G. F.; Ruminski, R. R.; Meyer, T. J. Long-Lived Near-Infrared MLCT Emitters. Inorg. Chem. 2001, 40, 4508-4509.

(50) Grosshenny, V.; Harriman, A.; Romero, F. M.; Ziessel, R. Electron Delocalization in Ruthenium(II) and Osmium(II) 2,2'Bipyridyl Complexes Formed from Ethynyl-Bridged Ditopic Ligands. J. Phys. Chem. 1996, 100, 17472-17484.

(51) Boyde, S.; Strouse, G. F.; Jones, W. E.; Meyer, T. J. The Effect on MLCT Excited States of Electronic Delocalization in the Acceptor Ligand. J. Am. Chem. Soc. 1990, 112, 7395-7396.

(52) Hung, C.-Y.; Wang, T.-L.; Jang, Y.; Kim, W. Y.; Schmehl, R. H.; Thummel, R. P. Dipyrido[4,3-b;5,6-b]acridine Derivatives and Their Ruthenium(II) Complexes. Inorg. Chem. 1996, 35, 5953-5956.

(53) Damrauer, N. H.; Boussie, T. R.; Devenney, M.; McCusker, J. K. Effects of Intraligand Electron Delocalization, Steric Tuning, and Excited-State Vibronic Coupling on the Photophysics of ArylSubstituted Bipyridyl Complexes of Ru(II). J. Am. Chem. Soc. 1997, $119,8253-8268$.

(54) Kober, E. M.; Sullivan, B. P.; Meyer, T. J. Solvent Dependence of Metal-to-Ligand Charge-Transfer Transitions. Evidence for Initial Electron Localization in MLCT Excited States of 2,2'-Bipyridine Complexes of Ruthenium(II) and Osmium(II). Inorg. Chem. 1984, 23, 2098-2104.

(55) Wang, Y.; Liu, S.; Pinto, M. R.; Dattelbaum, D. M.; Schoonover, J. R.; Schanze, K. S. Excited-State Structure and Delocalization in Ruthenium(II)-Bipyridine Complexes That Contain Phenyleneethynylene Substituents. J. Phys. Chem. A 2001, 105, 11118-11127.

(56) Wang, X.; Del Guerzo, A.; Schmehl, R. H. Photophysical Behavior of Transition Metal Complexes Having Interacting Ligand Localized and Metal-to-Ligand Charge Transfer States. J. Photochem. Photobiol., C 2004, 5, 55-77.

(57) Howarth, A. J.; Majewski, M. B.; Wolf, M. O. Photophysical Properties and Applications of Coordination Complexes Incorporating Pyrene. Coord. Chem. Rev. 2015, 282-283, 139-149.

(58) Zhang, X.; Hou, Y.; Xiao, X.; Chen, X.; Hu, M.; Geng, X.; Wang, Z.; Zhao, J. Recent Development of the Transition Metal Complexes Showing Strong Absorption of Visible Light and LongLived Triplet Excited State: From Molecular Structure Design to Photophysical Properties and Applications. Coord. Chem. Rev. 2020, 417, 213371.

(59) Mongin, C.; Moroz, P.; Zamkov, M.; Castellano, F. N. Thermally Activated Delayed Photoluminescence from PyrenylFunctionalized CdSe Quantum Dots. Nat. Chem. 2018, 10, 225-230.

(60) McClenaghan, N. D.; Leydet, Y.; Maubert, B.; Indelli, M. T.; Campagna, S. Excited-State Equilibration: A Process Leading to Long-Lived Metal-to-Ligand Charge Transfer Luminescence in Supramolecular Systems. Coord. Chem. Rev. 2005, 249, 1336-1350.

(61) Wilson, G. J.; Sasse, W. H. F.; Mau, A. W. H. Singlet and Triplet Energy Transfer Processes in Ruthenium(II) Bipyridine Complexes Containing Covalently Bound Arenes. Chem. Phys. Lett. 1996, 250, 583-588.
(62) Wilson, G. J.; Launikonis, A.; Sasse, W. H. F.; Mau, A. W.-H. Excited-State Processes in Ruthenium(II) Bipyridine Complexes Containing Covalently Bound Arenes. J. Phys. Chem. A 1997, 101, $4860-4866$

(63) Simon, J. A.; Curry, S. L.; Schmehl, R. H.; Schatz, T. R.; Piotrowiak, P.; Jin, X.; Thummel, R. P. Intramolecular Electronic Energy Transfer in Ruthenium(II) Diimine Donor/Pyrene Acceptor Complexes Linked by a Single C-C Bond. J. Am. Chem. Soc. 1997, $119,11012-11022$.

(64) Indelli, M. T.; Ghirotti, M.; Prodi, A.; Chiorboli, C.; Scandola, F.; McClenaghan, N. D.; Puntoriero, F.; Campagna, S. Solvent Switching of Intramolecular Energy Transfer in Bichromophoric Systems: Photophysics of (2,2'-Bipyridine)tetracyanoruthenate(II)/ Pyrenyl Complexes. Inorg. Chem. 2003, 42, 5489-5497.

(65) Tyson, D. S.; Henbest, K. B.; Bialecki, J.; Castellano, F. N. Excited State Processes in Ruthenium(II)/Pyrenyl Complexes Displaying Extended Lifetimes. J. Phys. Chem. A 2001, 105, 81548161.

(66) Tyson, D. S.; Castellano, F. N. Intramolecular Singlet and Triplet Energy Transfer in a Ruthenium(II) Diimine Complex Containing Multiple Pyrenyl Chromophores. J. Phys. Chem. A 1999, 103, 10955-10960.

(67) Tyson, D. S.; Bialecki, J.; Castellano, F. N. Ruthenium(II) Complex with a Notably Long Excited State Lifetime. Chem. Commun. 2000, 2355-2356.

(68) Baba, A. I.; Shaw, J. R.; Simon, J. A.; Thummel, R. P.; Schmehl, R. H. The Photophysical Behavior of $\mathrm{d}^{6}$ Complexes having Nearly Isoenergetic MLCT and Ligand Localized Excited States. Coord. Chem. Rev. 1998, 171, 43-59.

(69) Ford, W. E.; Rodgers, M. A. J. Reversible Triplet-Triplet Energy Transfer within a Covalently Linked Bichromophoric Molecule. J. Phys. Chem. 1992, 96, 2917-2920.

(70) Grusenmeyer, T. A.; Chen, J.; Jin, Y.; Nguyen, J.; Rack, J. J.; Schmehl, R. H. pH Control of Intramolecular Energy Transfer and Oxygen Quenching in $\mathrm{Ru}(\mathrm{II})$ Complexes having Coupled Electronic Excited States. J. Am. Chem. Soc. 2012, 134, 7497-7506.

(71) Morales, A. F.; Accorsi, G.; Armaroli, N.; Barigelletti, F.; Pope, S. J. A.; Ward, M. D. Interplay of Light Antenna and Excitation "Energy Reservoir" Effects in a Bichromophoric System based on Ruthenium-Polypyridine and Pyrene Units Linked by a Long and Flexible Poly(ethylene glycol) Chain. Inorg. Chem. 2002, 41, 67116719.

(72) Kozlov, D. V.; Tyson, D. S.; Goze, C.; Ziessel, R.; Castellano, F. N. Room Temperature Phosphorescence from Ruthenium(II) Complexes Bearing Conjugated Pyrenylethynylene Subunits. Inorg. Chem. 2004, 43, 6083-6092.

(73) Kerzig, C.; Wenger, O. S. Sensitized Triplet-Triplet Annihilation Upconversion in Water and its Application to Photochemical Transformations. Chem. Sci. 2018, 9, 6670-6678.

(74) Maubert, B.; McClenaghan, N. D.; Indelli, M. T.; Campagna, S. Absorption Spectra and Photophysical Properties of a Series of Polypyridine Ligands Containing Appended Pyrenyl and Anthryl Chromophores and of Their Ruthenium(II) and Osmium(II) Complexes. J. Phys. Chem. A 2003, 107, 447-455.

(75) Hissler, M.; Harriman, A.; Khatyr, A.; Ziessel, R. Intramolecular Triplet Energy Transfer in Pyrene-Metal Polypyridine Dyads: A Strategy for Extending the Triplet Lifetime of the Metal Complex. Chem. - Eur. J. 1999, 5, 3366-3381.

(76) El-Ghayoury, A.; Harriman, A.; Khatyr, A.; Ziessel, R. Intramolecular Triplet Energy Transfer in Metal Polypyridine Complexes Bearing Ethynylated Aromatic Groups. J. Phys. Chem. A 2000, 104, 1512-1523.

(77) El-Ghayoury, A.; Harriman, A.; Ziessel, R. Developing Osmium(II) Tris(2,2'-bipyridyl) Derivatives as Reagents for Luminogenic Assays. Chem. Commun. 1999, 2027-2028.

(78) Spaenig, F.; Olivier, J.-H.; Prusakova, V.; Retailleau, P.; Ziessel, R.; Castellano, F. N. Excited-State Properties of Heteroleptic Iridium(III) Complexes Bearing Aromatic Hydrocarbons with Extended Cores. Inorg. Chem. 2011, 50, 10859-10871. 
(79) Edkins, R. M.; Fucke, K.; Peach, M. J. G.; Crawford, A. G.; Marder, T. B.; Beeby, A. Syntheses, Structures, and Comparison of the Photophysical Properties of Cyclometalated Iridium Complexes Containing the Isomeric 1- and 2-(2'-pyridyl)pyrene Ligands. Inorg. Chem. 2013, 52, 9842-9860.

(80) Constable, E. C.; Neuburger, M.; Rösel, P.; Schneider, G. E.; Zampese, J. A.; Housecroft, C. E.; Monti, F.; Armaroli, N.; Costa, R. D.; Ortí, E. Ligand-Based Charge-Transfer Luminescence in Ionic Cyclometalated Iridium(III) Complexes Bearing a Pyrene-Functionalized Bipyridine Ligand: A Joint Theoretical and Experimental Study. Inorg. Chem. 2013, 52, 885-897.

(81) Michalec, J. F.; Bejune, S. A.; Cuttell, D. G.; Summerton, G. C.; Gertenbach, J. A.; Field, J. S.; Haines, R. J.; McMillin, D. R. LongLived Emissions from 4'-substituted $\mathrm{Pt}$ (trpy) $\mathrm{Cl}^{+}$Complexes Bearing Aryl Groups. Influence of Orbital Parentage. Inorg. Chem. 2001, 40, 2193-2200.

(82) Whited, M. T.; Djurovich, P. I.; Roberts, S. T.; Durrell, A. C.; Schlenker, C. W.; Bradforth, S. E.; Thompson, M. E. Singlet and Triplet Excitation Management in a Bichromophoric Near-InfraredPhosphorescent BODIPY-Benzoporphyrin Platinum Complex. J. Am. Chem. Soc. 2011, 133, 88-96.

(83) Lazzaro, D. P.; Fanwick, P. E.; McMillin, D. R. Arylated versus Cyclometalated Platinum(II) Polypyridines: Photoluminescence from $\mathrm{Pt}$ (4'-R-trpy) $\mathrm{Ph}^{+}$Systems $\left(\mathrm{R}=\mathrm{NMe}_{2}, \mathrm{~N}\right.$-pyrrolidinyl, or 1-pyrenyl). Inorg. Chem. 2012, 51, 10474-10476.

(84) Stacey, O. J.; Ward, B. D.; Coles, S. J.; Horton, P. N.; Pope, S. J. A. Chromophore-Labelled, Luminescent Platinum Complexes: Syntheses, Structures, and Spectroscopic Properties. Dalton Trans. 2016, 45, 10297-10307.

(85) Wolcan, E.; Torchia, G.; Tocho, J.; Piro, O. E.; Juliarena, P.; Ruiz, G.; Féliz, M. R. Photoinduced Charge Separation in $\mathrm{R}-\mathrm{CO}_{2}-$ $\operatorname{Re}(\mathrm{CO})_{3}\left(2,2^{\prime}\right.$-bipyridine $)$ Complexes. Two Emitting Charge Transfer Excited States. J. Chem. Soc., Dalton Trans. 2002, 2194-2202.

(86) Duchanois, T.; Etienne, T.; Beley, M.; Assfeld, X.; Perpète, E. A.; Monari, A.; Gros, P. C. Heteroleptic Pyridyl-Carbene Iron Complexes with Tuneable Electronic Properties. Eur. J. Inorg. Chem. 2014, 2014, 3747-3753.

(87) Dierks, P.; Päpcke, A.; Bokareva, O. S.; Altenburger, B.; Reuter, T.; Heinze, K.; Kühn, O.; Lochbrunner, S.; Bauer, M. Ground- and Excited-State Properties of Iron(II) Complexes Linked to Organic Chromophores. Inorg. Chem. 2020, 59, 14746-14761.

(88) Büldt, L. A.; Guo, X.; Vogel, R.; Prescimone, A.; Wenger, O. S. A Tris(diisocyanide)chromium(0) Complex Is a Luminescent Analog of Fe(2,2'-Bipyridine $)_{3}{ }^{2+}$. J. Am. Chem. Soc. 2017, 139, 985-992.

(89) Mann, K. R.; Cimolino, M.; Geoffroy, G. L.; Hammond, G. S.; Orio, A. A.; Albertin, G.; Gray, H. B. Electronic Structures and Spectra of Hexakisphenylisocyanide Complexes of $\operatorname{Cr}(0), \operatorname{Mo}(0)$, $\mathrm{W}(0), \mathrm{Mn}(\mathrm{I})$, and $\mathrm{Mn}(\mathrm{II})$. Inorg. Chim. Acta 1976, 16, 97-101.

(90) Mann, K. R.; Gray, H. B.; Hammond, G. S. Excited-State Reactivity Patterns of Hexakisarylisocyano Complexes of Chromium(0), Molybdenum(0), and Tungsten(0). J. Am. Chem. Soc. 1977, 99, 306-307.

(91) Sattler, W.; Ener, M. E.; Blakemore, J. D.; Rachford, A. A.; LaBeaume, P. J.; Thackeray, J. W.; Cameron, J. F.; Winkler, J. R.; Gray, H. B. Generation of Powerful Tungsten Reductants by Visible Light Excitation. J. Am. Chem. Soc. 2013, 135, 10614-10617.

(92) Sattler, W.; Henling, L. M.; Winkler, J. R.; Gray, H. B. Bespoke Photoreductants: Tungsten Arylisocyanides. J. Am. Chem. Soc. 2015, 137, 1198-1205.

(93) Kvapilová, H.; Sattler, W.; Sattler, A.; Sazanovich, I. V.; Clark, I. P.; Towrie, M.; Gray, H. B.; Záliš, S.; Vlček, A. Electronic Excited States of Tungsten(0) Arylisocyanides. Inorg. Chem. 2015, 54, 85188528

(94) Büldt, L. A.; Guo, X.; Prescimone, A.; Wenger, O. S. A Molybdenum(0) Isocyanide Analogue of $\mathrm{Ru}\left(2,2^{\prime} \text {-Bipyridine }\right)_{3}{ }^{2+}: \mathrm{A}$ Strong Reductant for Photoredox Catalysis. Angew. Chem., Int. Ed. 2016, 55, 11247-11250.
(95) Herr, P.; Wenger, O. S. Excited-State Relaxation in Luminescent Molybdenum(0) Complexes with Isocyanide Chelate Ligands. Inorganics 2020, 8, 14.

(96) Bilger, J. B.; Kerzig, C.; Larsen, C. B.; Wenger, O. S. A Photorobust $\mathrm{Mo}(0)$ Complex Mimicking $\left[\mathrm{Os}\left(2,2^{\prime} \text {-bipyridine }\right)_{3}\right]^{2+}$ and Its Application in Red-to-Blue Upconversion. J. Am. Chem. Soc. 2021, 143, 1651-1663.

(97) Luo, Y.-R. Comprehensive handbook of chemical bond energies; CRC Press: Boca Raton, 2007.

(98) Plummer, D. T.; Angelici, R. J. Synthesis and Characterization of Homoleptic Complexes of the Chelating Bidentate Isocyano Ligand tert-BuDiNC. Inorg. Chem. 1983, 22, 4063-4070.

(99) Stewart, M. A.; Moore, C. E.; Ditri, T. B.; Labios, L. A.; Rheingold, A. L.; Figueroa, J. S. Electrophilic functionalization of wellbehaved manganese monoanions supported by m-terphenyl isocyanides. Chem. Commun. 2011, 47, 406-408.

(100) Salsi, F.; Neville, M.; Drance, M.; Hagenbach, A.; Figueroa, J. S.; Abram, U. $\left\{\mathrm{M}^{\mathrm{I}}(\mathrm{CO}) \mathrm{X}\left(\mathrm{CNAr}{ }^{\mathrm{DArF} 2}\right)_{4}\right\}\left(\mathrm{DArF}=3,5-\left(\mathrm{CF}_{3}\right)_{2} \mathrm{C}_{6} \mathrm{H}_{3}\right.$; $\mathrm{M}=\mathrm{Re}$ and $\mathrm{Tc} ; \mathrm{X}=\mathrm{Br}$ and $\mathrm{Cl}$ ) Complexes: Convenient Platforms for the Synthesis of Low-Valent Rhenium and Technetium Compounds. Organometallics 2021, 40, 1336-1343.

(101) Till, M.; Kelly, J. A.; Ziegler, C. G. P.; Wolf, R.; Guo, T.; Ringenberg, M. R.; Lutsker, E.; Reiser, O. Synthesis and characterization of bidentate isonitrile iron complexes. Organometallics 2021, 40, 1042-1052.

(102) Einstein, A. Über die von der molekularkinetischen Theorie der Wärme geforderte Bewegung von in ruhenden Flüssigkeiten suspendierten Teilchen. Ann. Phys. 1905, 322, 549-560.

(103) Suzuki, K.; Kobayashi, A.; Kaneko, S.; Takehira, K.; Yoshihara, T.; Ishida, H.; Shiina, Y.; Oishi, S.; Tobita, S. Reevaluation of Absolute Luminescence Quantum Yields of Standard Solutions using a Spectrometer with an Integrating Sphere and a Back-Thinned CCD Detector. Phys. Chem. Chem. Phys. 2009, 11, 9850-9860.

(104) Catalán, J.; López, V.; Pérez, P.; Martin-Villamil, R.; Rodríguez, J.-G. Progress Towards a Generalized Solvent Polarity Scale: The Solvatochromism of 2-(Dimethylamino)-7-nitrofluorene and its Homomorph 2-Fluoro-7-nitrofluorene. Liebigs Ann. 1995, 1995, 241-252.

(105) Lippert, E. Dipolmoment und Elektronenstruktur von angeregten Molekülen. Z. Z. Naturforsch., A: Phys. Sci. 1955, 10, $541-545$.

(106) Mataga, N.; Kaifu, Y.; Koizumi, M. Solvent Effects upon Fluorescence Spectra and the Dipolemoments of Excited Molecules. Bull. Chem. Soc. Jpn. 1956, 29, 465-470.

(107) Herr, P.; Glaser, F.; Büldt, L. A.; Larsen, C. B.; Wenger, O. S. Long-Lived, Strongly Emissive, and Highly Reducing Excited States in Mo(0) Complexes with Chelating Isocyanides. J. Am. Chem. Soc. 2019, 141, 14394-14402.

(108) Chábera, P.; Kjaer, K. S.; Prakash, O.; Honarfar, A.; Liu, Y.; Fredin, L. A.; Harlang, T. C. B.; Lidin, S.; Uhlig, J.; Sundström, V.; Lomoth, R.; Persson, P.; Wärnmark, K. Fe ${ }^{\mathrm{II}}$ Hexa N-Heterocyclic Carbene Complex with a 528 ps Metal-to-Ligand Charge-Transfer Excited-State Lifetime. J. Phys. Chem. Lett. 2018, 9, 459-463.

(109) Draper, S. M.; Gregg, D. J.; Schofield, E. R.; Browne, W. R.; Duati, M.; Vos, J. G.; Passaniti, P. Complexed Nitrogen Heterosuperbenzene: The Coordinating Properties of a Remarkable Ligand. J. Am. Chem. Soc. 2004, 126, 8694-8701.

(110) Yoshimura, A.; Hoffman, M. Z.; Sun, H. An Evaluation of the Excited State Absorption Spectrum of $\mathrm{Ru}(\mathrm{bpy})_{3}{ }^{2+}$ in Aqueous and Acetonitrile Solutions. J. Photochem. Photobiol., A 1993, 70, 29-33.

(111) Damrauer, N. H.; Weldon, B. T.; McCusker, J. K. Theoretical Studies of Steric Effects on Intraligand Electron Delocalization: Implications for the Temporal Evolution of MLCT Excited States. J. Phys. Chem. A 1998, 102, 3382-3397.

(112) Sun, Y.; Turro, C. Highly Solvent Dependent Luminescence from $\left[\mathrm{Ru}(\mathrm{bpy})_{\mathrm{n}}\left(\mathrm{dppp}_{2}\right)_{3-\mathrm{n}}\right]^{2+}(\mathrm{n}=0-2)$. Inorg. Chem. 2010, 49, $5025-5032$.

(113) Brennaman, M. K.; Meyer, T. J.; Papanikolas, J. M. $\left[\mathrm{Ru}(\mathrm{bpy})_{2} \mathrm{dppz}\right]^{2+}$ Light-Switch Mechanism in Protic Solvents as 
Studied through Temperature-Dependent Lifetime Measurements ${ }^{\dagger}$. J. Phys. Chem. A 2004, 108, 9938-9944.

(114) Friedman, A. E.; Chambron, J. C.; Sauvage, J. P.; Turro, N. J.; Barton, J. K. A molecular Light Switch for DNA: Ru(bpy $)_{2}(\mathrm{dppz})^{2+}$. J. Am. Chem. Soc. 1990, 112, 4960-4962.

(115) Scandola, F.; Indelli, M. T. Second sphere donor acceptor interactions in excited states of coordination compounds. Ruthenium(II) bipyridine cyano complexes. Pure Appl. Chem. 1988, 60, 973980.

(116) Kjær, K. S.; Kunnus, K.; Harlang, T. C. B.; Van Driel, T. B.; Ledbetter, K.; Hartsock, R. W.; Reinhard, M. E.; Koroidov, S.; Li, L.; Laursen, M. G.; Biasin, E.; Hansen, F. B.; Vester, P.; Christensen, M.; Haldrup, K.; Nielsen, M. M.; Chabera, P.; Liu, Y.; Tatsuno, H.; Timm, C.; Uhlig, J.; Sundstöm, V.; Németh, Z.; Szemes, D. S.; Bajnóczi, E.; Vankó, G.; Alonso-Mori, R.; Glownia, J. M.; Nelson, S.; Sikorski, M.; Sokaras, D.; Lemke, H. T.; Canton, S. E.; Wärnmark, K.; Persson, P.; Cordones, A. A.; Gaffney, K. J. Solvent control of charge transfer excited state relaxation pathways in $\left[\mathrm{Fe}\left(2,2^{\prime}\right.\right.$-bipyridine $)$ $\left.(\mathrm{CN})_{4}\right]^{2-}$. Phys. Chem. Chem. Phys. 2018, 20, 4238-4249.

(117) Caspar, J. V.; Kober, E. M.; Sullivan, B. P.; Meyer, T. J. Application of the Energy Gap Law to the Decay of Charge-Transfer Excited States. J. Am. Chem. Soc. 1982, 104, 630-632.

(118) Creutz, C.; Chou, M.; Netzel, T. L.; Okumura, M.; Sutin, N. Lifetimes, Spectra, and Quenching of the Excited States of Polypyridine Complexes of Iron(II), Ruthenium(II), and Osmium(II). J. Am. Chem. Soc. 1980, 102, 1309-1319.

(119) Leshchev, D.; Harlang, T. C. B.; Fredin, L. A.; Khakhulin, D.; Liu, Y.; Biasin, E.; Laursen, M. G.; Newby, G. E.; Haldrup, K.; Nielsen, M.; Wärnmark, K.; Sundström, V.; Persson, P.; Kjær, K. S.; Wulff, M. Tracking the Picosecond Deactivation Dynamics of a Photoexcited Iron Carbene Complex by Time-resolved X-ray Scattering. Chem. Sci. 2018, 9, 405-414.

(120) McCusker, J. K.; Walda, K. N.; Dunn, R. C.; Simon, J. D.; Magde, D.; Hendrickson, D. N. Subpicosecond ${ }^{1}$ MLCT $\rightarrow{ }^{5} \mathrm{~T}_{2}$ Intersystem Crossing of Low-spin Polypyridyl Ferrous Complexes. J. Am. Chem. Soc. 1993, 115, 298-307.

(121) Juban, E. A.; Smeigh, A. L.; Monat, J. E.; McCusker, J. K. Ultrafast Dynamics of Ligand-Field Excited States. Coord. Chem. Rev. 2006, 250, 1783-1791.

(122) Kjær, K. S.; Zhang, W.; Alonso-Mori, R.; Bergmann, U.; Chollet, M.; Hadt, R. G.; Hartsock, R. W.; Harlang, T.; Kroll, T.; Kubiček, K.; Lemke, H. T.; Liang, H. W.; Liu, Y.; Nielsen, M. M.; Robinson, J. S.; Solomon, E. I.; Sokaras, D.; van Driel, T. B.; Weng, T.-C.; Zhu, D.; Persson, P.; Wärnmark, K.; Sundström, V.; Gaffney, K. J. Ligand manipulation of charge transfer excited state relaxation and spin crossover in $\left[\mathrm{Fe}\left(2,2^{\prime} \text {-bipyridine }\right)_{2}(\mathrm{CN})_{2}\right]$. Struct. Dyn. 2017, 4, 044030.

(123) Soupart, A.; Alary, F.; Heully, J.-L.; Elliott, P. I. P.; Dixon, I. M. Recent Progress in Ligand Photorelease Reaction Mechanisms: Theoretical Insights Focusing on $\mathrm{Ru}(\mathrm{II}){ }^{3} \mathrm{MC}$ States. Coord. Chem. Rev. 2020, 408, 213184.

(124) Dorn, M.; Kalmbach, J.; Boden, P.; Päpcke, A.; Gómez, S.; Förster, C.; Kuczelinis, F.; Carrella, L. M.; Büldt, L. A.; Bings, N. H.; Rentschler, E.; Lochbrunner, S.; González, L.; Gerhards, M.; Seitz, M.; Heinze, K. A Vanadium(III) Complex with Blue and NIR-II SpinFlip Luminescence in Solution. J. Am. Chem. Soc. 2020, 142, 79477955.

(125) Chan, K.-T.; Lam, T.-L.; Yu, D.; Du, L.; Phillips, D. L.; Kwong, C.-L.; Tong, G. S. M.; Cheng, G.; Che, C.-M. Strongly Luminescent Tungsten Emitters with Emission Quantum Yields of up to $84 \%$ : TADF and High-Efficiency Molecular Tungsten OLEDs. Angew. Chem., Int. Ed. 2019, 58, 14896-14900.

(126) Herr, P.; Kerzig, C.; Larsen, C. B.; Häussinger, D.; Wenger, O. $\mathrm{S}$. Manganese(I) complexes with metal-to-ligand charge transfer luminescence and photoreactivity. Nat. Chem. 2021. DOI: 10.1038/ s41557-021-00744-9. 